\title{
Bank Lending Relationships and the Use of Performance-Sensitive Debt
}

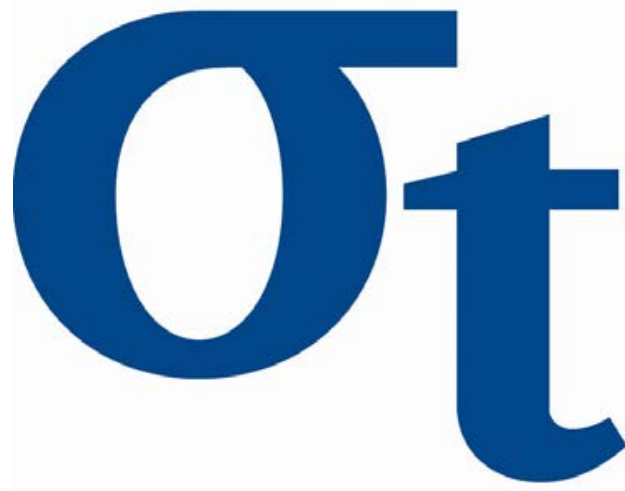

の

$\checkmark$

6

ด

(1)

* Humboldt-Universität zu Berlin, Germany

This research was supported by the Deutsche Forschungsgemeinschaft through the SFB 649 "Economic Risk".

http://sfb649. wiwi.hu-berlin.de ISSN 1860-5664 


\title{
Bank Lending Relationships and the Use of
}

\author{
Performance-Sensitive Debt
}

\author{
TIM R. ADAM and DANIEL STREITZ*
}

\begin{abstract}
We show that performance-sensitive debt (PSD) is used to reduce hold-up problems in repeated lending relationships. Using a large sample of bank loans, we find a more frequent use of PSD if hold-up is more likely, e.g. if a longterm lending relationship exists and the borrower has fewer outside financing alternatives. The use of PSD is less likely in syndicated relationship loans, as hold-up is less important in this market. Finally, we find a substitution effect between the use of PSD and the tightness of financial covenants, which is consistent with PSD reducing hold-up problems caused by the use of covenants.
\end{abstract}

Keywords: Performance-Sensitive Debt, Relationship Lending, Hold-Up, Covenants

JEL-Classification: G21, G31, G32

${ }^{*}$ Tim R. Adam and Daniel Streitz are from the Institute of Corporate Finance at Humboldt University Berlin. The authors wish to thank Darwin Choi, Hans Christensen, Rüdiger Fahlenbrach, Gustavo Manso, Mark Seasholes and Sascha Steffen, as well as seminar participants at HKUST and ESTM (Berlin) for helpful comments and suggestions. The authors would also like to thank Paolo Bizzozero for excellent research assistance. The authors gratefully acknowledge support from the Deutsche Forschungsgemeinschaft through the Collaborative Research Centers SFB 649 "Economic Risk" and SFB/TR15 "Governance and the Efficiency of Economic Systems". Contact information: Tim Adam, Tel.: +49(0)30 2093 5641, e-mail: tim.adam@hu-berlin.de; Daniel Streitz, Tel.: +49(0)30 20935624 , e-mail: daniel.streitz@hu-berlin.de. 


\title{
Bank Lending Relationships and the Use of
}

\section{Performance-Sensitive Debt}

\begin{abstract}
We show that performance-sensitive debt (PSD) is used to reduce hold-up problems in repeated lending relationships. Using a large sample of bank loans, we find a more frequent use of PSD if hold-up is more likely, e.g. if a longterm lending relationship exists and the borrower has fewer outside financing alternatives. The use of PSD is less likely in syndicated relationship loans, as hold-up is less important in this market. Finally, we find a substitution effect between the use of PSD and the tightness of financial covenants, which is consistent with PSD reducing hold-up problems caused by the use of covenants.
\end{abstract}

Keywords: Performance-Sensitive Debt, Relationship Lending, Hold-Up, Covenants

JEL-Classification: G21, G31, G32 
Since the late 1990s, many bank loans have contained performance pricing provisions which imply that the coupon paid rises as the firm's financial performance deteriorates and falls if it improves. Financial performance is measured using either the borrower's credit rating or a financial ratio such as a leverage ratio. The theoretical literature has linked performance-sensitive debt (PSD) to debt renegotiation costs, asset substitution and signaling considerations. Asquith et al. (2005) argue that PSD reduces debt renegotiation costs due to adverse selection, moral hazard, or unanticipated changes in the borrower's credit risk. Koziol and Lawrenz (2010) show that PSD can mitigate risk-shifting incentives in the presence of moral hazard, ${ }^{1}$ while Manso et al. (2010) demonstrate that PSD can be used as a signaling device for a firm's credit quality in a setting with adverse selection.

While these theories clearly explain some of the variation in the use of PSD, it remains a puzzle as to why PSD is rare in public but common in private debt markets. ${ }^{2}$ Furthermore, even rated firms often issue PSD based on a financial ratio rather than the borrower's credit rating. Since a rating should, in most cases, better reflect a borrower's credit risk than a single financial ratio, the motivation for using PSD based on a financial ratio must go beyond pure credit risk considerations.

We explore a new explanation for the use of PSD which is consistent with PSD being common in the private debt market but uncommon in the public bond market, and which explains why firms use PSD based on financial ratios instead of credit ratings: PSD is

1 In contrast, Bhanot and Mello (2006) argue that PSD is an inefficient method to reduce incentives for asset substitution.

2 Using keyword searches on both Bloomberg and EDGAR Pro, we are able to identify only 115 public bond issues from 74 distinct companies between 1989 and 2012. In contrast, about 50\% of loans reported by LPC Dealscan contain performance pricing provisions. 
used to mitigate hold-up problems in long-term lending relationships. Sharpe (1990) and Rajan (1992) show that one cost of relationship lending is the potential for hold-up by the lender. This is because the lender invests in the acquisition of borrower-specific private information. The resulting information advantage of the lender makes it difficult for the borrower to switch to another, less well informed lender due to adverse selection. This is especially the case for opaque borrowers, which have fewer financing alternatives. If the borrower is "locked in", the bank can exploit the situation by charging higher interest rates or by denying interest rate reductions when the borrower's performance improves. Schmidt (2006) argues that the use of covenants, which is common in private debt contracts, further exacerbates the hold-up problem because covenants shift bargaining power from borrowers to lenders. Von Thadden (1995) shows that a solution to this hold-up problem is to pre-specify contract terms ex ante, thereby limiting the discretion of the lender. Indeed, PSD contracts limit the discretion of the lender because they pre-specify the loan contract terms should a borrower's performance deteriorate or improve. In this case, the lender cannot demand undue interest rate increases (above what is justified by borrower risk alone) if the borrower's performance deteriorates and a covenant is violated, or deny interest rate reductions if the borrower's performance improves. Because covenants are based on financial ratios rather than a firm's credit rating, it is necessary to issue PSD based on a financial ratio in order to reduce hold-up induced by covenants. ${ }^{3}$

Our paper is the first to analyze explicitly the link between the hold-up problem in

\footnotetext{
3 A performance pricing provision can also be valuable for a lender who is trying to attract high quality borrowers because it acts as a commitment device not to expropriate a borrower.
} 
repeated lending relationships and the use of PSD contracts. Using a large sample of private debt contracts issued by non-financial U.S. borrowers between 1990 and 2009, we show that accounting-based PSD contracts, i.e. PSD based on a financial ratio, are about $35 \%$ more likely to be used in repeated lending relationships after we control for endogeneity of the lending relationship. As proposed by Bharath et al. (2011), we use the spherical distance between the borrower's and the lender's headquarters as an instrument for relationship strength. In contrast, we find no significant correlations between the use of rating-based PSD and the presence of a repeated lending relationship. We further analyze whether the use of PSD varies systematically across different types of borrowers. Santos and Winton (2008) argue that the costs of relationship lending are higher for companies which do not have access to other financing sources (e.g. bond market access). In line with this argument, we find that accounting-based PSD contracts are more common in relationship lending arrangements with smaller firms, firms that are not included in the S\&P 500 Index and firms that do not have a long-term issuer credit rating at the time of the loan origination. If a loan is syndicated, performance pricing provisions are less likely, which is consistent with hold-up being of less importance in syndicated loan deals.

The hold-up problem is especially severe in the presence of covenants. Consistent with the argument by Schmidt (2006), we find a positive association between the presence of covenants and the use of PSD. ${ }^{4}$ Furthermore, a majority of PSD have covenants on the same performance measure as the one used in the performance-pricing provision, with covenant thresholds typically set directly at the end of the pricing grid. However, if

\footnotetext{
${ }^{4}$ Asquith et al. (2005) also find that most PSD contracts contain financial covenants.
} 
performance pricing provisions are used to mitigate the hold-up problem, then there should be a substitution effect between the pricing grid of rate-increasing $\operatorname{PSD}^{5}$ and covenant tightness: covenants should be less tight compared to covenants of debt without PSD. ${ }^{6}$ This is what we find. Debt-to-EBITDA covenants, the most common covenant type in our loan sample, are less tight in PSD contracts that also use Debt-to-EBITDA as a measure of the borrower's performance compared with debt without PSD. Consistent with the substitution hypothesis, this effect exists only for interest-increasing PSD contracts. ${ }^{7}$

Finally, we examine the evolution of the borrower's credit rating 1-2 years following the issue of PSD, to examine the possibility that PSD is used to signal credit quality, as proposed by Manso et al. (2010). We find that borrowers credit ratings tend to improve over 1-2 years following the issue of rating-based but not accounting-based PSD. These results are consistent with the hypothesis that rating-based PSD is used to signal credit quality, while accounting-based PSD is used to address potential hold-up problems in repeated lending relationships. ${ }^{8}$

We make two contributions to the literature. Firstly, we offer a new explanation for using PSD, namely that PSD reduces potential hold-up problems in repeated lending relationships. In contrast, Manso et al. (2010) argue that borrowers use PSD to signal

5 PSD that allows for interest rate increases only.

6 Small deteriorations in a borrower's performance, which would otherwise trigger a technical default now automatically lead to interest rate increases as determined by the pricing grid. Thus, a substitution effect should exist for interest-increasing PSD contracts only.

7 Consistent with the substitution argument, Nikolaev (2011) shows that PSD contracts are less likely to be renegotiated than regular debt.

8 Performance-pricing provisions in public debt are exclusively based on the issuer's credit rating. Since hold-up is of no concern in public bond markets, this result further supports our conclusion that accounting-based PSD and rating-based PSD is used for different purposes. 
their credit quality, while Koziol and Lawrenz (2010) argue that PSD reduces moral hazard. The study that is closest to our own is Asquith et al. (2005). These authors argue that the use of PSD reduces debt renegotiation costs, which can arise in the presence of adverse selection, moral hazard and unexpected changes in the borrower's credit risk. They find that interest-decreasing PSD is used if loan prepayment is more likely and renegotiation costs are higher (as in syndicated loans). Interest-increasing PSD is used if there is a greater probability that the debt will be downgraded. In contrast, we argue that accounting-based PSD reduces a borrower's switching costs to a new lender, which are large if hold-up is likely. Consistent with this hypothesis, we find that the use of accounting-based PSD is more likely if the firm borrows from a relationship lender and if the firm has few borrowing alternatives outside the relationship. Furthermore, the use of accounting-based PSD is less likely if a loan is syndicated, while the renegotiation cost hypothesis would predict the opposite. The use of rating-based PSD, on the other hand, appears to be consistent with theories based on adverse selection.

Secondly, our results provide indirect evidence that hold-up in repeated lending relationships can be of significant concern, and that borrowers and lenders take appropriate actions to prevent it. Several authors find evidence which is consistent with the presence of hold-up. Saunders and Steffen (2011) find that private firms pay higher loan spreads when borrowing from a relationship bank, while public firms benefit from lower spreads. Hale and Santos (2009) show that banks adjust their loan interest rates downwards after a firm's bond IPO. Santos and Winton (2008) find that (all else equal) loan spreads of 
bank-dependent borrowers rise more during recessions than loan spreads of borrowers who have access to public debt markets. Freudenberg et al. (2011) show that contract terms deteriorate more for borrowers that switch lenders after having violated a covenant in the previous loan compared to borrowers that stay with the same lender. Mattes et al. (2012) find that capital-constrained (European) banks charge borrowers with high switching costs higher loan spreads than well-capitalized banks. This effect prevails only during recessions. Degryse and Cayseele (2000) find evidence for a deterioration of contract terms over the lending relationship for a sample of European firms. ${ }^{9}$ As argued by Boot (2000), acquiring multiple bank relationships can be one potential solution for this problem. ${ }^{10}$ However, Ongena and Smith (2000) show that this may reduce the availability of credit, because increased competition reduces the value of information acquisition and hence the incentive to lend to "young" firms. ${ }^{11}$ We extend this literature by linking the use of PSD to the hold-up problem in repeated lending relationships.

The remainder of the paper proceeds as follows. Section I presents our hypotheses.

Section II describes the sample selection process, outlines the construction of variables,

9 There is also considerable evidence of the benefits of lending relationships. Petersen and Rajan (1994) find that the duration of a bank-firm relationship does not influence the contracted loan rate, but Berger and Udell (1995) document that rates on lines of credit and collateral requirements decrease with the duration of the bank-firm relationship. Bharath et al. (2011) find that repeated borrowing from the same lender translates into a 10-17 bps lowering of loan spreads, and that relationships are especially valuable when borrower transparency is low. See Boot and Thakor (2000), Elsas and Krahnen (1998), Freudenberg et al. (2011), Berlin and Mester (1998), Bharath et al. (2007), Bharath et al. (2011), and Schenone (2010) for further empirical evidence on the benefits of lending relationships.

${ }^{10}$ Houston and James (1996) find that firms with a single bank relationship use less bank debt, as growth opportunities are higher. Farinha and Santos (2002) find that firms with higher growth opportunities or greater bank dependence are more likely to switch to multiple bank relationships. All of the abovementioned evidence is consistent with the notion that multiple bank relationships reduce the hold-up problems.

11 The availability of funds to young firms without a track record is one potential benefit of relationship lending as shown by Petersen and Rajan (1995). Banks can "subsidize" borrowers in earlier periods in return for higher rents in future periods if they have an information monopoly. 
and presents some descriptive findings. Section III contains the main empirical analysis, which demonstrates a link between relationship lending and the use of performance pricing provisions. Section IV explores alternative explanations, and Section V concludes.

\section{Hypothesis Development}

Sharpe (1990) and Rajan (1992) show that a long-term lending relationship creates an information asymmetry between the relationship lender and other potential lenders, which can be costly for the borrower. Adverse selection can make it difficult for the borrower to switch to another lender. The relationship lender can take advantage of its information monopoly and extract some rents from the borrower. This is especially the case in the event of covenant violations, because in these situations, much bargaining power rests with the lender. Von Thadden (1995) argues that one way of reducing this hold-up problem is to limit the discretion of the lender by using pre-specified contract terms. PSD can be regarded as such a pre-specification of contract terms. PSD contracts specify higher (lower) interest payments if the borrower's performance deteriorates (improves) in the future. Using PSD, the relationship lender could not deny interest rate reductions should a borrower's performance subsequently improve. Similarly, the relationship lender could not unduly increase the interest rate in case of a covenant violation. A PSD contract thus limits the discretion of the lender. Since hold-up is more likely in repeated relationship lending, we will test the following hypothesis. 
Hypothesis 1. Relationship loans are more likely to include performance-pricing provisions than non-relationship loans.

Covenant violations in particular expose borrowers to the possibility of hold-up. To protect against hold-up in these situations, borrowers would need to pre-specify the terms that apply if the firm were to violate a covenant. Covenants on a firm's leverage ratio are frequent, while covenants on a firm's credit rating are virtually non-existent. We therefore expect Hypothesis 1 to hold primarily for PSD based on the same performance measures as used in debt covenants, i.e. accounting-based PSD.

Santos and Winton (2008) argue that the severity of the hold-up problem can vary systematically across different types of borrowers. For example, the degree to which a borrower is "locked in" in a lending relationship depends on the availability of other financing sources, such as public bond market access, and the opaqueness of the borrower. This gives rise to a second hypothesis:

Hypothesis 2. Firms with fewer outside financing alternatives that borrow from a relationship lender are more likely to use performance-sensitive debt.

One can differentiate between purely interest-increasing and purely interest-decreasing PSD. Interest-increasing pricing grids allow for rate increases only, while interest-decreasing pricing grids allow for rate decreases only. There is no obvious connection between interest-decreasing PSD and covenants. However, if PSD is used to pre-specify the contract terms in the case of a hypothetical covenant violation, then there should be a 
substitution effect between the use of interest-increasing PSD and the threshold at which a covenant ultimately kicks in. We therefore test the following hypothesis.

Hypothesis 3. Interest-increasing performance-sensitive loans have less tight covenants on the same performance measure, which is also used in the pricing grid.

Manso et al. (2010) argue that PSD is used to signal a firm's credit quality, which should apply primarily to rating-based PSD. For the signal to be credible, issuers' credit rating should improve on average following the issuance of rating-based PSD. Manso et al. (2010) show that this is indeed the case. If accounting-based PSD are motivated by hold-up considerations, then there is reason to observe systematic improvements in credit quality following the issuance of accounting-based PSD. We therefore test the following hypothesis.

Hypothesis 4. Issuer credit ratings improve following the issue of rating-based PSD, but do not change systematically following the issue of accounting-based PSD.

\section{Data Description}

We obtain our loan sample from the Thomson Reuters Loan Pricing Corporation Dealscan (LPC's Dealscan) database, which contains detailed information on corporate loan issues. We restrict our sample to loans issued by U.S. non-financial borrowers between 1990 and 2009. Following Tchistyi et al. (2011), we further restrict our sample to loans with LIBOR-based spreads to achieve comparability across loan observations. A loan 
can consist of several different tranches, each with potentially different contract characteristics. Since we perform our analysis with loan-level data, we either calculate sums or value-weighted averages over all loan tranches, where the weights are determined by the relative tranche amounts. We obtain information on loan characteristics such as maturity, the loan amount (scaled by total assets), number of covenants, as well as the loan purpose and loan type. In addition, we record whether a loan is secured or not. We then merge our loan data with borrower-specific information obtained from Standard and Poor's Compustat North America database, such as firm size, market-to-book etc., from the last available fiscal quarter before the loan issue. ${ }^{12}$ The Appendix contains the definitions of all variables used in our analysis.

\section{A. Performance-Sensitive Debt Contracts}

Dealscan reports whenever performance pricing provisions are included in a loan contract. The most common performance measure used in PSD contracts is the Debt-to-EBITDA ratio ( $\sim 44 \%$ of all PSD loans issued by U.S. borrowers) followed by the issuer's senior debt rating $(\sim 27 \%)$. Dealscan also reports the exact pricing grid, i.e. the function which links the coupon payments to the performance measure. Figure 1 shows the pricing grid of a loan issued by Urban Outfitters Inc. in September 2007. The spread paid by Urban Outfitters increases with its Debt-to-EBITDA ratio (accounting-based PSD). Urban Outfitter's Debt-to-EBITDA ratio at the time of the issue was 4, meaning that

\footnotetext{
${ }^{12}$ We use Michael Robert's Dealscan-Compustat Linking Database to merge Dealscan with Compustat (see Chava and Roberts (2008)).
} 
this loan is an example of a rate-increasing contract. Figure 2 shows the pricing grid of a loan issued by IBM in March 2004. In this contract, the loan spread changes with IBM's senior debt rating (rating-based PSD). Since IBM's senior debt rating at the time of the issue was $\mathrm{A}+$, this loan is an example of a rate-increasing and rate-decreasing contract.

[Figures $1 \& 2$ here]

\section{B. Measuring Relationship Strength}

We follow Bharath et al. (2011) and construct three proxies for the strength of the lending relationship between borrower and lender. To construct these proxies, we first need to identify the lead lender(s) for each loan contract. As in Sufi (2007), we classify a lender as the lead lender if the variable "Lead Arranger Credit" (provided by LPC's Dealscan) takes on the value "Yes", or if the lender is the only lender specified in the loan contract. Next, we search the borrowing record of the borrower over the past five years. The first proxy for the strength of the lending relationship, Rel(Dummy), is a dummy variable which equals one if the firm borrowed from the same lead lender in the previous five years and zero otherwise. ${ }^{13}$ If there are multiple lead lenders in a loan, we calculate the proxy separately for each lender and assign the highest value to the loan. The second

\footnotetext{
${ }^{13}$ Note that Dealscan often classifies borrowers at the subsidiary level. E.g. General Electric Capital Canada and General Electric Capital Corp of Puerto Rico are two distinct borrowers in Dealscan. By using the Michael Robert's Dealscan-Compustat Linking Database, all wholly-owned subsidiaries are effectively aggregated under the ultimate parent. We also manually aggregate the lenders under the ultimate parent. (E.g. Lehman Brothers Inc [Frankfurt] and Lehman Brothers Asia are two distinct lenders in Dealscan). This procedure is important to ensure that, e.g. a switch from Lehman Brothers Inc [Frankfurt] to Lehman Brothers Asia is not classified as an actual lender switch. Not aggregating the borrowers and lenders under the ultimate parent, however, does not affect our results qualitatively.
} 
proxy, Rel(Number), measures the relative number of loans obtained from the relationship lender. For bank $m$ lending to borrower $i$, it is calculated as follows.

$$
\operatorname{Rel}(\text { Number })_{m}=\frac{\text { Number of loans by bank } m \text { to borrower } i \text { in the last } 5 \text { years }}{\text { Total number of loans by borrower } i \text { in the last } 5 \text { years }}
$$

Again, the highest value is assigned to a loan if there are multiple lead lenders. The third proxy, Rel(Amount), measures the relative loan amounts obtained from the relationship lender. For bank $m$ lending to borrower $i$, it is calculated as follows.

$$
\operatorname{Rel}(\text { Amount })_{m}=\frac{\text { Amount of loans by bank } m \text { to borrower } i \text { in the last } 5 \text { years }(\$)}{\text { Total amount of loans by borrower } i \text { in the last } 5 \text { years }(\$)}
$$

Again, the highest value is assigned to a loan if there are multiple lead lenders.

\section{Measuring the Tightness of Covenants}

As noted by Demiroglu and James (2010), covenant slack, i.e. the difference between the covenant variable at the initiation of the loan agreement and the covenant threshold, is an intuitive measure for covenant tightness. However, the degree of tightness also depends on the volatility of the covenant variable and is thus firm-specific. We therefore follow Demiroglu and James (2010) and define covenant tightness as the difference between the 
covenant variable at the initiation of the loan agreement and the covenant threshold, normalized by the standard deviation of the covenant variable over the previous twelve quarters. ${ }^{14}$

Since in practice, leverage and liquidity ratios are defined in various ways we restrict our analysis to covenants on the Debt-to-EBITDA ratio, which, as Demiroglu and James (2010) note, has the most consistent definition (see also Dichev and Skinner (2002)).

\section{Descriptive Statistics}

Table 1 presents descriptive statistics for our sample consisting of 17,902 loans issued by 4,769 distinct borrowers between 1990 and 2009. Following Bharath et al. (2011), the data are winsorized at the $1 \%$ and $99 \%$ levels to remove outliers. Panel A reports loan characteristics which are consistent with prior studies (e.g. Sufi (2007)). For example, the mean/median deal amounts in our sample are $\$ 415 / \$ 175$ million, which is large given the mean/median book value of assets of $\$ 4,034 / \$ 783$ million and an average leverage ratio of $25 \%$. The average all-in-drawn spread is 161 basis points, and the average maturity is 3.5 years. $77 \%$ of loans are credit lines. Loan contracts on average include 1.6 covenants, ranging from 0 to 8 . Consistent with Manso et al. (2010), roughly $50 \%$ of loans include a

\footnotetext{
${ }^{14}$ The tightness of covenants can also be measured by a covenant intensity index that ranges from zero to six, with higher values indicating stricter covenants as proposed by Bradley and Roberts (2004). The index is constructed by summing indicator variables on dividend restrictions, equity sweep, asset sweep, debt sweep, securitization and a binary variable that equals one if the contract includes two or more financial covenants. Murfin (2011) further considers covariation between the different covenant variables when measuring contract strictness. We do not use these indices in our context because we are interested in the tightness of a particular covenant, i.e. the covenant on the same ratio, which is used in the loan pricing grid.
} 
performance-pricing provision. Panel B reports borrower characteristics. Most loans are issued by borrowers that have a credit rating around the investment grade threshold. In $47 \%$ of cases, borrowers do not have a credit rating at all. Panel C reports descriptive statistics on the three relationship lending proxies. A lending relationship exists in $59 \%$ of all loan contracts. On average, $35 \%$ of the total capital raised over the course of 5 years was raised from the same lead lender.

[Table 1 here]

Table 2 shows the various performance measures used in PSD contracts. The most common performance measure is the Debt-to-EBITDA ratio (44\%), followed by the senior debt rating $(27 \%)$. The remaining performance measures are various leverage ratios. In at least $5 \%$ of cases, multiple performance measures are used. We define PSD as accountingbased PSD whenever an accounting ratio is used as a measure of firm performance. Rating-based PSD comprise all PSD contracts, which use the borrower's credit rating as a performance measure.

[Table 2 here] 


\section{Results}

\section{A. Lending Relationships and the Use of Performance-Sensitive}

\section{Debt}

We begin by analyzing the interaction between lending relationships and the choice between PSD and straight debt. As noted in Section II, we distinguish between accountingbased and rating-based PSD. We therefore estimate a multinomial logistic regression.

$$
P S D_{i t}=\alpha+\alpha_{I n d}+\alpha_{t}+\alpha_{\text {Rat }}+\beta * \operatorname{Rel}(M)_{i t}+\gamma * X_{i t}+\epsilon_{i t}
$$

The dependent variable, $P S D$, is a discrete variable, which equals one if the loan contract contains a performance pricing provision on an accounting measure, two if the loan contract includes a performance pricing provision on the borrower's credit rating, and zero in the case of straight debt (control group). $\operatorname{Rel}(M)$ represents one of our three measures of relationship strength, and $X$ are control variables to control for heterogeneity in borrower and loan characteristics. We follow Manso et al. (2010) and use firm size, measured by the log of total assets, the market-to-book ratio of assets, leverage, the loan amount (scaled by total assets), the deal maturity, indicator variables for credit lines and secured loans, and the number of covenants as control variables. We also include loan purpose indicators (corporate purpose, refinancing, and takeover), time fixed effects, 
industry fixed effects and dummy variables for each rating level. We cluster the standard errors at the firm level to account for non-independent observations within firms. Table 3 reports the regression results.

[Table 3 here]

Consistent with Hypothesis 1, we find that relationship strength is positively and significantly correlated with the use of accounting-based PSD, while relationship strength appears to be uncorrelated with the use of rating-based PSD. Consistent with the existing literature on PSD (e.g. Tchistyi et al. (2011)), larger borrowers, larger loan amounts and credit lines are more likely to include a performance pricing provision. Loan maturity is positively correlated with the use of accounting-based PSD, which is consistent with our hypothesis that performance pricing provisions are used in contracts with a higher renegotiation likelihood. Loan contracts are more likely to be renegotiated if the maturity is longer. We further find that secured loans are less likely to include a rating-based performance pricing provision, but more likely to include an accounting-based performance pricing provision. These initial results show that it is the accounting-based PSD contracts which may be motivated by hold-up due to lending relationships, while ratingbased PSD are more likely to be motivated by other considerations such as signaling or asset-substitution. In the following analysis, we therefore exclude rating-based PSD and return to the issue of signaling in Section IV.

The decision to form and stay in a lending relationship is clearly an endogenous choice which has been recognized in a number of recent studies, e.g. Agarwal and Hauswald 
(2010), Bharath et al. (2011), Coval and Moskowitz (2001), Dass and Massa (2011), Degryse and Ongena (2005), Norden and Weber (2010), and Petersen and Rajan (2002). We follow this literature and use the geographic distance between the borrower and the lead lender as an instrument for relationship strength. This instrument is likely to be correlated with the decision to form a lending relationship but unlikely to be correlated with the decision to include a performance pricing provision in the loan contract. Lenders that are physically closer to a borrower are more likely to have better information about a borrower, and are hence more likely to become a relationship lender. We match the location of the borrowers' and lenders' headquarters, provided by Dealscan, to the MaxMind World Cities Database to obtain information on the longitude and latitude. ${ }^{15}$ We are always able to identify the lender and the borrower location in MaxMind if the information on the location is provided by Dealscan. We treat observations as missing if the exact location of the lender or the borrower is not specified in Dealscan, which reduces the sample by 2,001 observations. We calculate the distance in miles between the borrower and the lead lender for each deal. ${ }^{16}$ We follow Petersen and Rajan (2002) and address skewness in the distance measure by using $\ln (1+$ Distance $)$ in the regressions.

Table 4 reports the results of the IV-estimation using linear probability models in computing 2SLS estimates and correcting the standard errors for heteroskedasticity. ${ }^{17}$

\footnotetext{
15 The MaxMind database contains geographical information for about 3 million places in 234 countries and is publicly available at http://www.maxmind.com/app/worldcities.

${ }^{16}$ We use the same estimation formula as in Dass and Massa (2011). We assign the minimum distance to the deal in case of multiple lead lenders. See the appendix for further details.

17 Angrist and Pischke (2009) argue that this procedure yields consistent estimates. Several studies find that linear probability models produce results similar to partial effects from more precise models (see e.g. Angrist and Pischke (2009) and Katz et al. (2001)). However, our results are not sensitive to the question of whether we use linear probability models or bivariate probit models as advocated by
} 
Consistent with Bharath et al. (2011), we find that $\ln (1+$ Distance $)$ is significantly negatively correlated to all three proxies for lending relationship strength, confirming the validity of the inclusion restriction. The results of the second stage regressions confirm our previous results that PSD contracts are more likely to be used in the presence of bank lending relationships. In fact, PSD contracts are about $35 \%$ more likely to be used in repeated lending relationships after we control for the endogeneity of the lending relationship, which is statistically and economically very significant. ${ }^{18}$

[Table 4 here]

Our results so far show that relationship lending is positively correlated with the use of PSD, which is consistent with our hypothesis that PSD reduces a potential hold-up problem in repeated lending relationships. However, the severity of the hold-up problem is likely to vary systematically across different types of borrowers. To obtain further identification, we consider cross-sectional differences in the strength of this correlation. For example, the severity of the hold-up problem is likely to depend on the opacity of the borrower as well as its alternative financing options. Following Bharath et al. (2011), we use firm size as well as a dummy variable which equals one if the borrower does not have a S\&P rating (and zero otherwise) as proxies for firm opacity. Another proxy for

\footnotetext{
Heckman (1978).

${ }^{18}$ As in other studies that use instruments in relationship lending settings, the economic significance strongly increases in the IV-estimation. For example, Bharath et al. (2011) use IV regressions to examine the impact of lending relationships on loan spreads and find that the effect is more than 5 times stronger when using the distance between borrower and lender as an instrument for relationship lending. Berger et al. (2005) use IV regressions to examine the relationship between bank size and the exclusivity of bank-borrower relationships. Instrumenting bank size, they show a large increase in economic importance of bank size when compared to the OLS estimates.
} 
opacity is membership in the S\&P 500 Index due to higher media and analyst coverage of these companies. Larger firms and rated firms are more likely to have multiple financing alternatives, and are thus less "locked in" in a bank lending relationship. We also use a dummy variable which equals one if a loan is syndicated, because firms borrowing from a syndicate should suffer less from hold-up problems. Another concern is that our results may be driven by a small number of lenders because, as Ross (2010) points out, the market for syndicated loans is dominated by three large banks. ${ }^{19}$ To address this concern, we follow Bharath et al. (2011) and include a dummy variable which equals one for loans made by one of the top 3 banks and zero otherwise.

To test for the cross-sectional variation in the severity of the hold-up problem induced by lending relationships, we estimate the following logit model.

$$
\begin{aligned}
P S D_{i t} & =\alpha+\alpha_{\text {Ind }}+\alpha_{t}+\alpha_{\text {Rat }}+\beta_{1} * \operatorname{Rel}(M)_{i t}+\beta_{2} * \text { BorrowerOpacity }_{i t} \\
& +\beta_{3} * \operatorname{Rel}(\text { Dummy })_{i t} * \text { BorrowerOpacity }{ }_{i t}+\gamma * X_{i t}+\epsilon_{i t}
\end{aligned}
$$

The dependent variable, $P S D$, is a dummy variable which equals one if a loan contract includes a performance pricing provision and zero otherwise. Rel(Dummy) is the indicator variable for the presence of a lending relationship. BorrowerOpacity represents the above-mentioned proxies for borrower opacity. We include interaction variables of relationship strength and BorrowerOpacity to examine the cross-sectional variation of the

${ }^{19}$ These are J.P. Morgan Chase, Bank of America and Citigroup. 
PSD-sensitivity. Due to the high correlation of the interaction variables, we include one at a time in the regressions. The results are reported in Table 5.

[Table 5 here]

The coefficients of all interaction variables of borrower opacity are negative and statistically significant, which is consistent with our hypothesis that opacity, and thus fewer alternative financing options, increases the severity of hold-up, and hence increases the likelihood of using PSD. In particular, the negative coefficient on Rel(Dummy)*ln(Assets) shows that PSD is less frequently used in relationship lending arrangements if the company is large and hence less opaque. The negative coefficient on Rel(Dummy)*Rated implies that companies which repeatedly borrow from the same lender but do not have a credit rating are more likely to use PSD. Similar conclusions can be drawn from the regression in Column 3, which uses membership in the S\&P 500 Index as a proxy for borrower opacity. Overall, our results support the hypothesis that the hold-up problem and thus the benefit of using PSD contracts is larger for more opaque borrowers.

A potential concern is that our loan sample is drawn from the LPC's Dealscan database, which contains large and predominantly - albeit not exclusively - syndicated loans. In general, firms in this sample should suffer less from hold-up problems than smaller firms. However, as noted by Santos and Winton (2008), using Dealscan should, if anything, create a bias against finding evidence of opportunistic bank behavior. Nevertheless, we differentiate between syndicated and non-syndicated loans. If hold-up problems 
are less severe for syndicated loans, performance pricing provisions should be used less frequently in syndicated loans. The results reported in Table 5 confirm this hypothesis. The coefficient on $\operatorname{Rel}($ Dummy $){ }^{*}$ Syndication is negative and statistically highly significant. ${ }^{20}$

This result is in contrast to the renegotiation cost hypothesis proposed by Asquith et al. (2005). According to this hypothesis, the use of PSD should be more likely in syndicated loans because renegotiation costs are higher if a loan is syndicated. However, we find the opposite to be the case.

Another concern is that the market for syndication is dominated by three large banks. We follow Bharath et al. (2011) and address this issue by including a dummy variable in our main regression which equals one if a loan is made by one of the top 3 banks and zero otherwise. Performance-sensitive debt should be less frequently used if the lending relationship is with one of the top 3 banks, because the top 3 banks are mostly transaction-oriented, so that hold-up problems are less severe in relationships with these lenders. The results reported in Table 5 confirm this hypothesis. The coefficient on Rel(Dummy)*Top-3 Bank is significantly negative. Rel(Dummy) remains positive and highly significant. ${ }^{21}$

${ }^{20}$ Our results are robust to excluding all syndicated loans from the sample and focusing exclusively on single-lender loans. The effect for $\operatorname{Rel}(\operatorname{Dummy})$ remains positive and highly significant at the $1 \%$ level with a marginal effect of $8 \%$. These results are available from the authors upon request.

${ }^{21}$ We also find that our results hold if we exclude all loans made by the top 3 banks from our sample. These results are available from the authors upon request. 


\section{B. Performance-Sensitive Debt and Covenants}

In this section, we investigate whether there is a substitution effect between the use of performance pricing grids and the tightness of financial covenants. In particular, Hypothesis 3 states that PSD contracts should have less tight covenants because the pricing grid pre-specifies the consequences of small changes in a borrower's performance, while only larger changes in a borrower's performance trigger a renegotiation due to covenant violations.

[Table 6 here]

Table 6 compares the frequency of covenant usage in PSD and straight debt contracts. Consistent with covenants increasing the likelihood of hold-up, we find that covenants are more commonly used in PSD contracts than in straight-debt contracts. Over $50 \%$ of PSD contracts include a covenant on Debt-to-EBITDA, while only $11 \%$ of non-PSD contracts include such a covenant. This fraction is even higher for debt which contains Debt-to-EBITDA pricing provisions: $86 \%$ of such PSD contracts also have a covenant on Debt-to-EBITDA (not reported).

[Table 7 here]

Table 7 compares the covenant threshold levels used in PSD and non-PSD contracts. We find that PSD contracts have leverage and liquidity covenants with lower default 
thresholds than non-PSD contracts. For example, the median Debt-to-EBITDA covenant level for PSD contracts is 3.5, with 3.75 for non-PSD contracts. This appears not to be supportive of Hypothesis 3. However, PSD and non-PSD are not unconditionally comparable, since borrower characteristics differ. A multivariate analysis is called for.

Furthermore, we now need to distinguish between interest-increasing and interestdecreasing PSD, because only interest-increasing PSD contracts should have an effect on covenant tightness. Interest-decreasing performance pricing provisions matter only if a borrowers performance improves. To ensure that covenants and a loan's performance pricing grid are based in the same variable, we restrict our analysis to covenants on the Debt-to-EBITDA ratio, which is the most frequently used performance measure in our sample.

Following Demiroglu and James (2010), we calculate the covenant tightness as the absolute difference between the Debt-to-EBITDA ratio at the initiation of the loan agreement and the Debt-to-EBITDA covenant threshold, normalized by the standard deviation of the borrower's Debt-to-EBITDA ratio over the previous twelve quarters. A lower ratio indicates a tighter covenant. ${ }^{22}$ We then estimate the following regression by OLS.

$$
\begin{aligned}
\text { Tightness }_{i t} & =\alpha+\alpha_{\text {Ind }}+\alpha_{t}+\alpha_{\text {Rat }}+\beta_{1} * \text { IncreasingPSD } D_{i t} \\
& +\beta_{2} * \text { MixedPSD } D_{i t}+\beta_{3} * \text { DecreasingPSD } D_{i t}+\gamma * X_{i t}+\epsilon_{i t}
\end{aligned}
$$

\footnotetext{
$\overline{22}$ We lose observations because we require 12 quarters before the loan issue with non missing observations on the Debt-to-EBITDA ratio to calculate the Debt-to-EBITDA standard deviation.
} 
The dependent variable, Tightness, is the tightness of the Debt-to-EBITDA covenant as defined above. $X$ represents loan and borrower characteristics. As before, we control for time, industry and rating fixed effects. Increasing $P S D$ is a dummy variable which equals one if the loan contains a pricing grid on Debt-to-EBITDA that only allows for interest rate increases. Decreasing $P S D$ is a dummy variable which equals one if the loan contains a pricing grid on Debt-to-EBITDA that allows for interest rate decreases only, and MixedPSD is a dummy variable which equals one if the loan contains a pricing grid on Debt-to-EBITDA that allows for both interest rate increases and decreases.

[Table 8 here]

As shown in Table 8, we find that interest-increasing PSD contracts have significantly less tight Debt-to-EBITDA covenants than straight debt. This is consistent with our hypothesis that performance-pricing affects covenant tightness: small changes in the credit risk of the borrower are regulated by performance-pricing provisions and not by tight covenants. We further find that more highly levered borrowers and loans with a larger number of covenants have tighter Debt-to-EBITDA covenants. Borrowers with more growth opportunities have less tight covenants. ${ }^{23}$

\footnotetext{
${ }^{23}$ The accuracy and coverage of covenants reported in the Dealscan database has improved over time. However, our results are not sensitive to this issue and remain virtually unchanged if we restrict the sample to loans issued after 2000. These results are available upon request.
} 


\section{Robustness: Hold-up vs. Signaling}

Manso et al. (2010) show that PSD can be used as a signaling device to signal a firm's credit quality. Only borrowers who expect their credit ratings not to deteriorate are willing to enter into contracts that stipulate interest rate increases should the firm's credit rating decline. To test whether signaling explains the use of rating-based PSD, Manso et al. (2010) analyze the post-issue credit rating development for firms that issue PSD vs. firms that issue straight debt. We replicate their analysis, but further distinguish between accounting-based and rating-based PSD, because the signaling hypothesis should predominantly apply to rating-based PSD, while the hold-up hypothesis predominantly applies to accounting-based PSD. In particular, we reestimate the following ordered probit regression.

$$
\begin{aligned}
\Delta \text { Rating }_{i t} & =\alpha+\alpha_{\text {Ind }}+\alpha_{t}+\beta_{1} * P S D(\text { Rat })_{i t} \\
& +\beta_{2} * P S D(A c c)_{i t}+\gamma * X_{i t}+\epsilon_{i t}
\end{aligned}
$$

Following Manso et al. (2010), $\Delta$ Rating $_{i}$ is a discrete variable that takes on one of three values: 1 if the borrower's credit rating improved in the first $k$ quarters after the loan issue, -1 if the borrower's credit rating declined in the first $k$ quarters after the loan issue, and 0 if the borrower's credit rating remained unchanged $(k=2,4,8) . P S D($ Rat $)$ is a dummy variable which equals one if the loan contains a pricing grid on the borrower's 
credit rating, while $P S D(A c c)_{i}$ is a dummy variable which equals one if the loan contains a pricing grid on an accounting measure. The regression results are reported in Table 9.

[Table 9 here]

Consistent with the results reported by Manso et al. (2010), we find that firms are more likely to experience a rating improvement up to two years after issuing a ratingbased PSD relative to borrowers who issued regular debt. However, our results show that this does not hold for accounting-based PSD. Accounting-based PSD contracts are thus unlikely to be motivated by signaling considerations.

\section{Conclusion}

Von Thadden (1995) argues that pre-specifying loan contract terms can be an efficient way to mitigate hold-up problems in long-term lending relationships. An example is performance-sensitive debt (PSD), which pre-specifies loan contract terms in events that would otherwise trigger debt renegotiation. In this paper, we test the hypothesis that accounting-based PSD is used to reduce potential hold-up problems in bank lending relationships.

Consistent with this hypothesis, we find that accounting-based PSD contracts are more likely to be used in relationship lending arrangements. This is especially the case if the borrower is opaque and has fewer financing alternatives, both of which imply a 
greater potential for hold-up. Furthermore, syndication appears to reduce the need for accounting-based PSD because hold-up is less likely in syndicated debt deals.

We also find a substitution effect between the pricing grid and the tightness of covenants. The Debt-to-EBITDA covenants of PSD contracts are less tight than the covenants of non-PSD contracts. This substitution effect is consistent with the recommendation by Von Thadden (1995) to pre-specify contract terms to mitigate hold-up.

In contrast to accounting-based PSD, the use of rating-based PSD is not correlated with relationship strength. Furthermore, while the issue of rating-based PSD is followed by rating improvements on average, this is not the case for accounting-based PSD. These results indicate that hold-up is an important determinant in the decision to issue accounting-based PSD, while signaling motivates the decision to issue rating- based PSD. 


\section{References}

Agarwal, S. and R. Hauswald (2010). Distance and private information in lending. Review of Financial Studies 23, 2757-2788.

Angrist, J. D. and J.-S. Pischke (2009). Mostly Harmless Econometrics: An Empiricists Companion. Princeton University Press.

Asquith, P., A. Beatty, and J. Weber (2005). Performance pricing in bank debt contracts. Journal of Accounting and Economics 40, 101-128.

Berger, A. N., N. H. Miller, M. A. Petersen, R. G. Rajan, and J. C. Stein (2005). Does function follow organizational form? evidence from the lending practices of large and small banks. Journal of Financial Economics 72, 237-69.

Berger, A. N. and G. F. Udell (1995). Relationship lending and lines of credit in small firm finance. The Journal of Business 68, 351-381.

Berlin, M. and L. J. Mester (1998). On the profitability and cost of relationship lending. Journal of Banking \& Finance 22, 873-897.

Bhanot, K. and A. S. Mello (2006). Should corporate debt include a rating trigger? Journal of Financial Economics 79, 69-98.

Bharath, S., S. Dahiyab, A. Saunders, and A. Srinivasan (2007). So what do i get? the bank ̌ss view of lending relationships. Journal of Financial Economics 85, 368-419. 
Bharath, S. T., S. Dahiya, A. Saunders, and A. Srinivasan (2011). Lending relationships and loan contract terms. The Review of Financial Studies 24, 1142-1203.

Boot, A. W. A. (2000). Relationship banking: What do we know? Journal of Financial Intermediation 9, 7-25.

Boot, A. W. A. and A. V. Thakor (2000). Can relationship banking survive competition? The Journal of Finance 55, 679-713.

Bradley, M. and M. R. Roberts (2004). The structure and pricing of corporate debt covenants. Working Paper.

Chava, S. and M. R. Roberts (2008). How does financing impact investment? the role of debt covenants. Journal of Finance 63, 2085 - 2121.

Coval, J. D. and T. J. Moskowitz (2001). The geography of investment: Informed trading and asset prices. Journal of Political Economy 109, 811-841.

Dass, N. and M. Massa (2011). The impact of a strong bank-firm relationship on the borrowing firm. Review of Financial Studies 24, 1204-1260.

Degryse, H. and P. V. Cayseele (2000). Relationship lending within a bank-based system: Evidence from european small business data. Journal of Financial Intermediation 9, 90-109.

Degryse, H. and S. Ongena (2005). Distance, lending relationships, and competition. The Journal of Finance 60, 231-266. 
Demiroglu, C. and C. M. James (2010). The information content of bank loan covenants. Review of Financial Studies 23, 3700-3737.

Dichev, I. D. and D. J. Skinner (2002). Large-sample evidence on the debt covenant hypothesis. Journal of Accounting Research 40, 1091-1123.

Elsas, R. and J. P. Krahnen (1998). Is relationship lending special? evidence from creditfile data in germany. Journal of Banking \& Finance 22, 1283 Ú1316.

Farinha, L. A. and J. A. C. Santos (2002). Switching from single to multiple bank lending relationships: Determinants and implications. Journal of Financial Intermediation 11, $124-151$.

Freudenberg, F., B. Imbierowicz, A. Saunders, and S. Steffen (2011). Covenant violations, loan contracting, and default risk of bank borrowers. Working Paper.

Hale, G. and J. A. C. Santos (2009). Do banks price their informational monopoly? Journal of Financial Economics 93, 185-206.

Heckman, J. J. (1978). Dummy endogenous variables in a simultaneous equation system. Econometria 46, 931-959.

Houston, J. F. and C. M. James (1996). Bank information monopolies and the mix of private and public debt claims. The Journal of Finance 51, 1863-1899.

Katz, L. F., J. R. Kling, and J. B. Liebman (2001). Moving to opportunity in boston: Early results of a randomized mobility experiment. The Quarterly Journal of Economics 116, 607-654. 
Koziol, C. and J. Lawrenz (2010). Optimal design of rating-trigger step-up bonds: Agency conflicts versus asymmetric information. Journal of Corporate Finance 16, 182-204.

Manso, G., B. Strulovici, and A. Tchistyi (2010). Performance-sensitive debt. Review of Financial Studies 23, 1819-1854.

Mattes, J. A., S. Steffen, and M. Wahrenburg (2012). Do information rents in loan spreads persist over the business cycles? Journal of Financial Services Research, 1-21.

Murfin, J. (2011). The supply-side determinants of loan contract strictness. The Journal of Finance, forthcoming.

Nikolaev, V. V. (2011). Scope for renegotiation and debt contract design. Working Paper.

Norden, L. and M. Weber (2010). Credit line usage, checking account activity, and default risk of bank borrowers. Review of Financial Studies 23, 3665-3699.

Ongena, S. and D. C. Smith (2000). What determines the number of bankrelationships? cross-country evidence. Journal of Financial Intermediation 9, 26-56.

Petersen, M. and R. Rajan (1995). The effect of credit market competition on lending relationships. Journal of Quarterly Economics 110, 406-443.

Petersen, M. A. and R. G. Rajan (1994). The benefits of lending relationships: Evidence from small business data. The Journal of Finance 49, 3-37.

Petersen, M. A. and R. G. Rajan (2002). Does distance still matter? the information revolution in small business lending. The Journal of Finance 57, 2533-2570. 
Rajan, R. G. (1992). Insiders and outsiders: The choice between informed and arm'slength debt. The Journal of Finance 47, 1367-1400.

Ross, D. G. (2010). The "dominant bank effect:" how high lender reputation affects the information content and terms of bank loans. Review of Financial Studies 23, $2730-2756$.

Santos, J. A. C. and A. Winton (2008). Bank loans, bonds, and information monopolies across the business cycle. The Journal of Finance 63, 1315-1359.

Saunders, A. and S. Steffen (2011). The costs of being private: Evidence from the loan market. Review of Financial Studies 24, 4091-4122.

Schenone, C. (2010). Lending relationships and information rents: Do banks exploit their information advantages? Review of Financial Studies 23, 1149-1199.

Schmidt, K. M. (2006). The economics of covenants as a means of efficient creditor protection. European Business Organization Law Review 7, 89-94.

Sharpe, S. A. (1990). Asymmetric information, bank lending and implicit contracts: A stylized model ofcustomer relationships. The Journal of Finance 45, 1069-1087.

Sufi, A. (2007). Information asymmetry and financing arrangements: Evidence from syndicated loans. The Journal of Finance 62, 629-668.

Tchistyi, A., D. Yermack, and H. Yun (2011). Negative hedging: Performance-sensitive debt and ceos' equity incentives. Journal of Financial and Quantitative Analysis 46, $657-686$. 
Von Thadden, E.-L. (1995). Long-term contracts, short-term investment and monitoring. Review of Economic Studies 62, 557-575. 


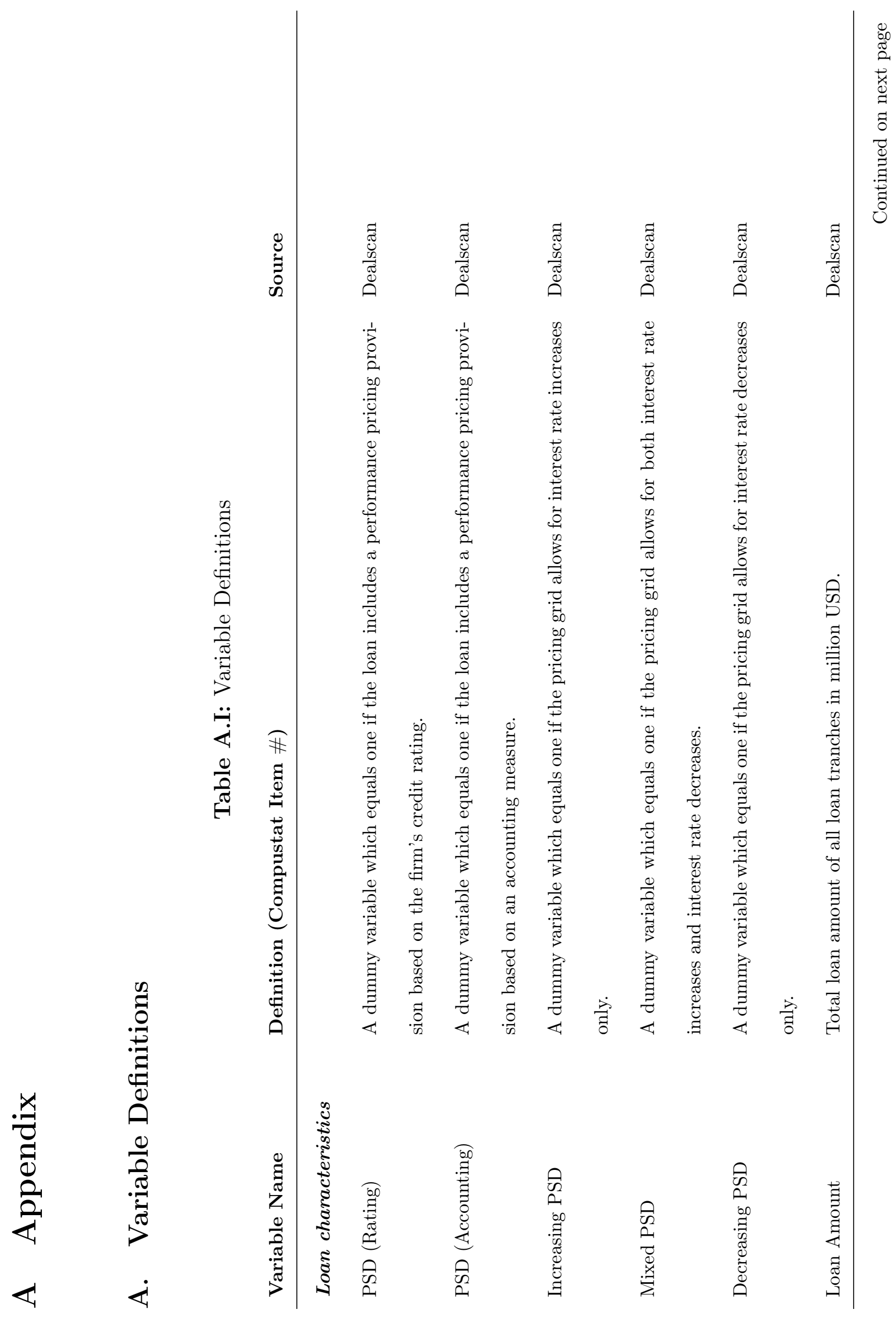




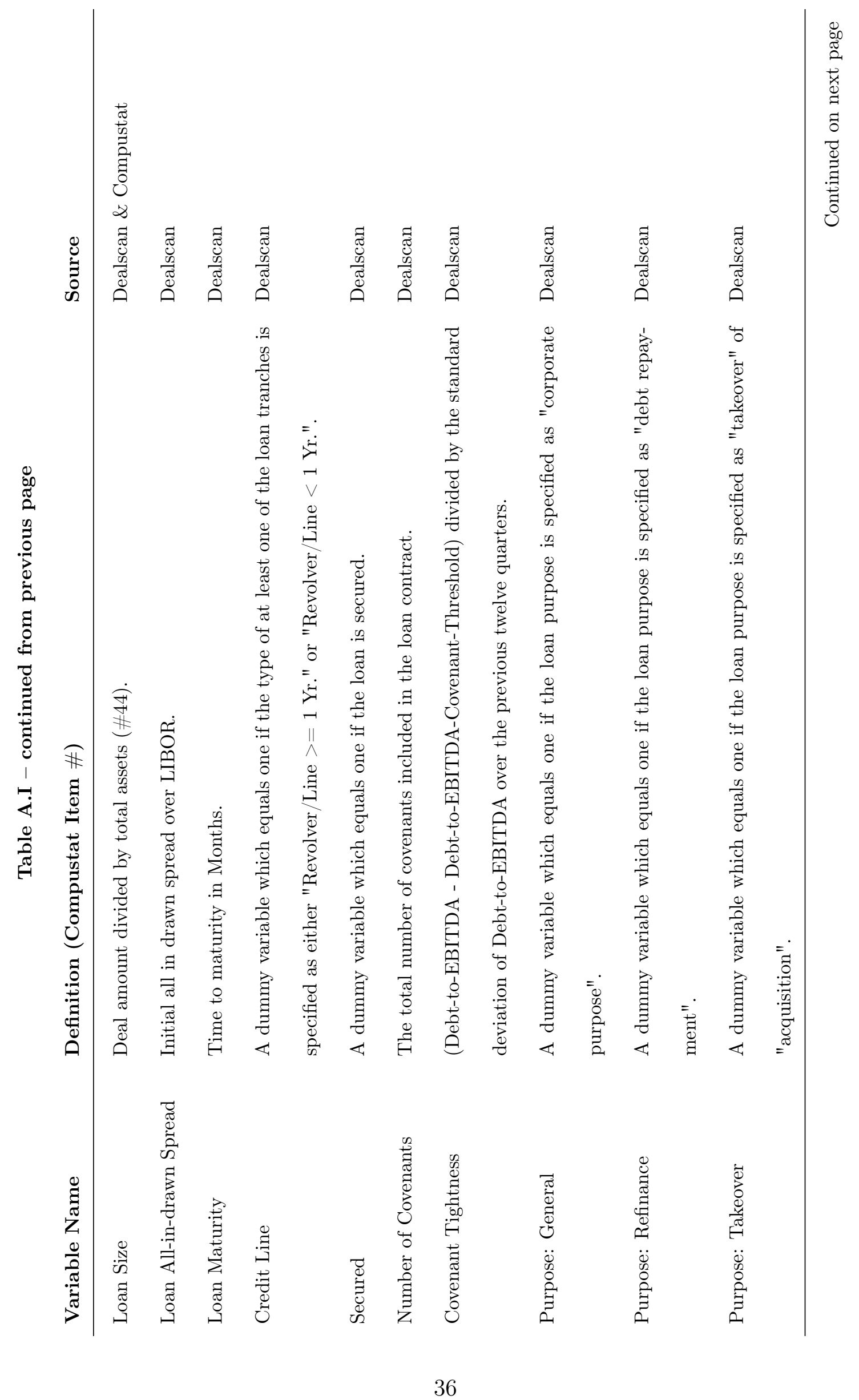




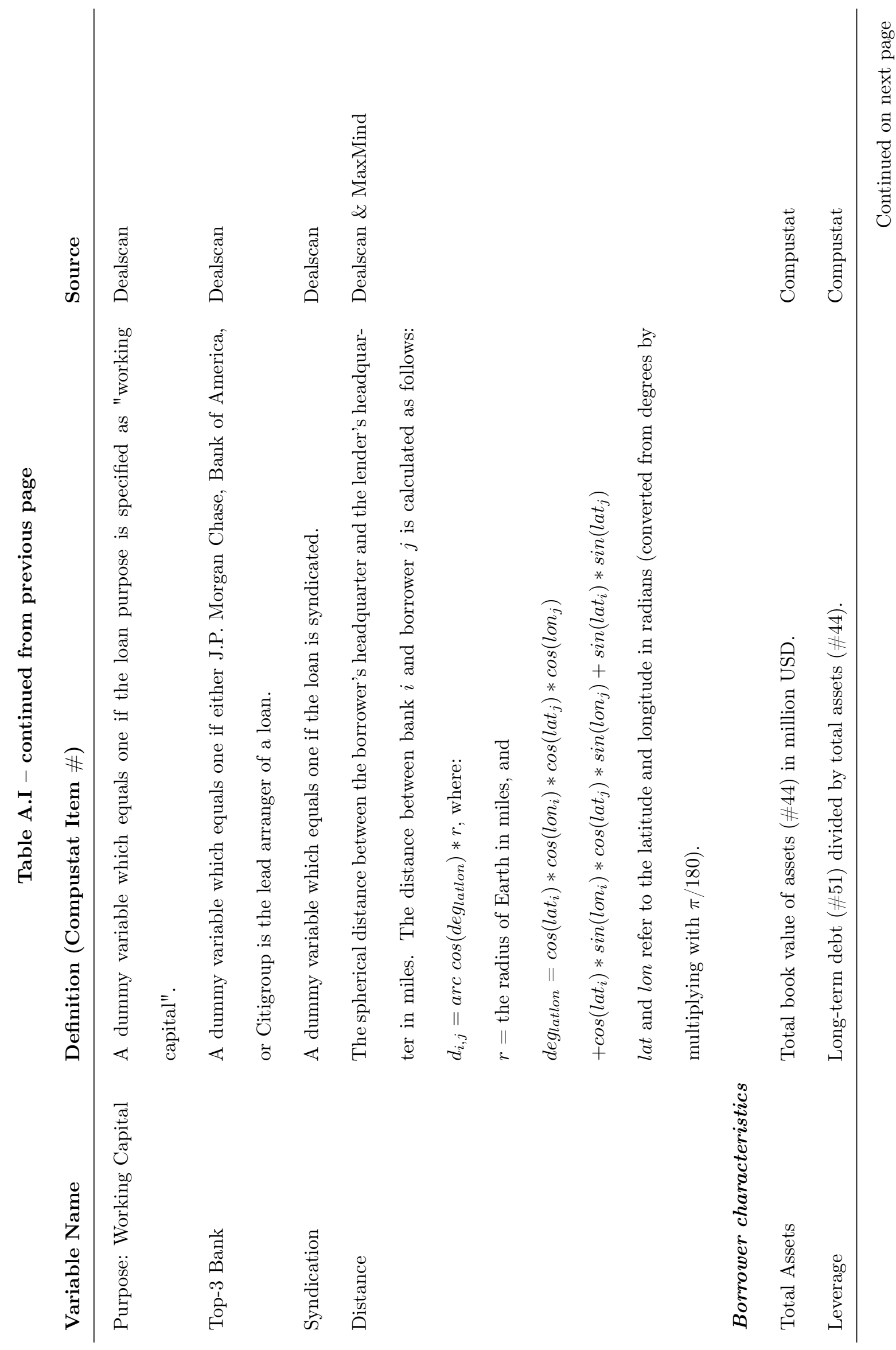




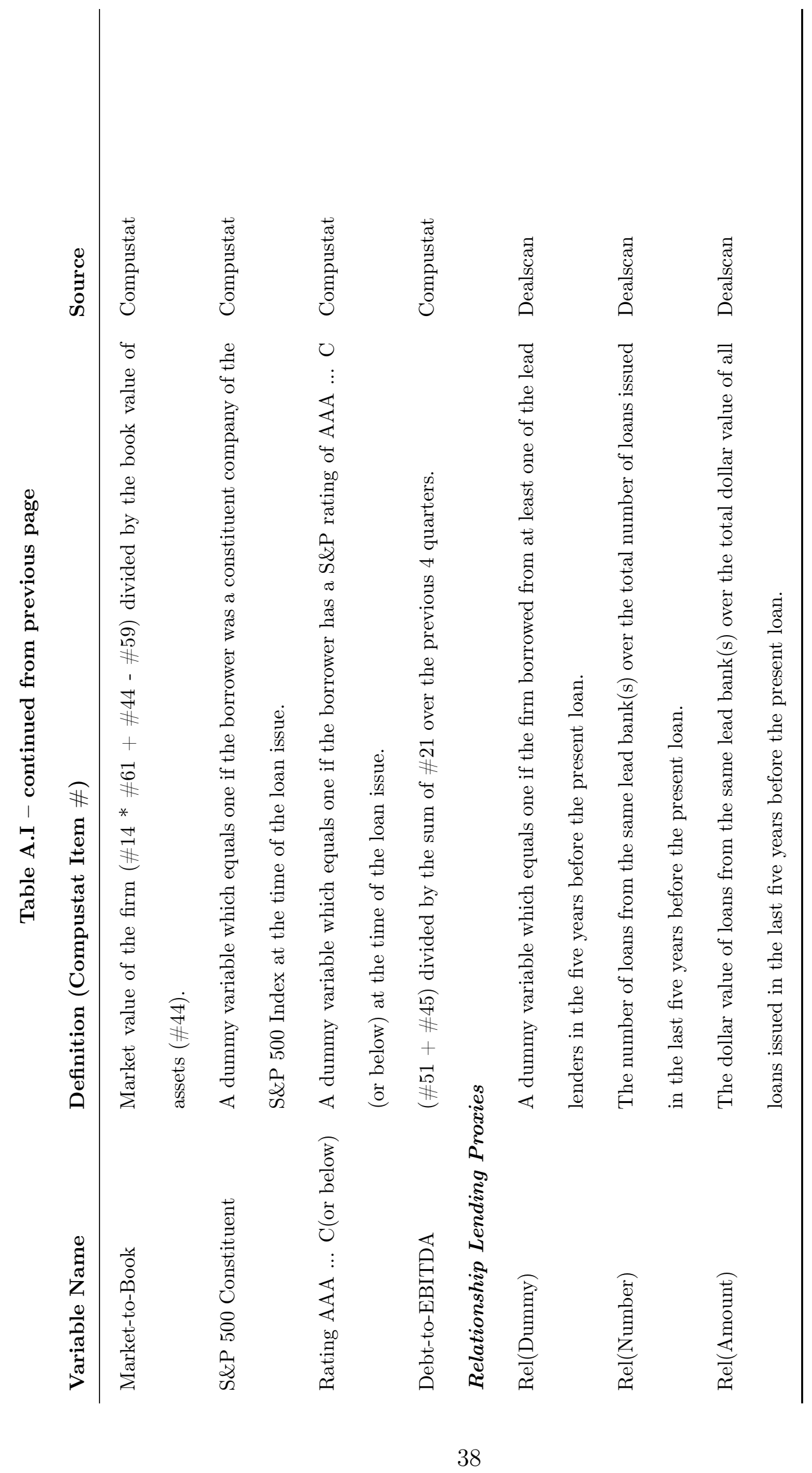




\section{B. Figures and Tables}

Figure 1: Accounting-Based PSD

This figure shows the pricing grid of a loan issued by Urban Outfitters Inc in 2007. The spread is contingent on the issuer's Debt-to-EBITDA ratio. The Debt-to-EBITDA ratio at the time of loan issue was 4 . The initial spread paid was LIBOR $+150 \mathrm{bp}$.

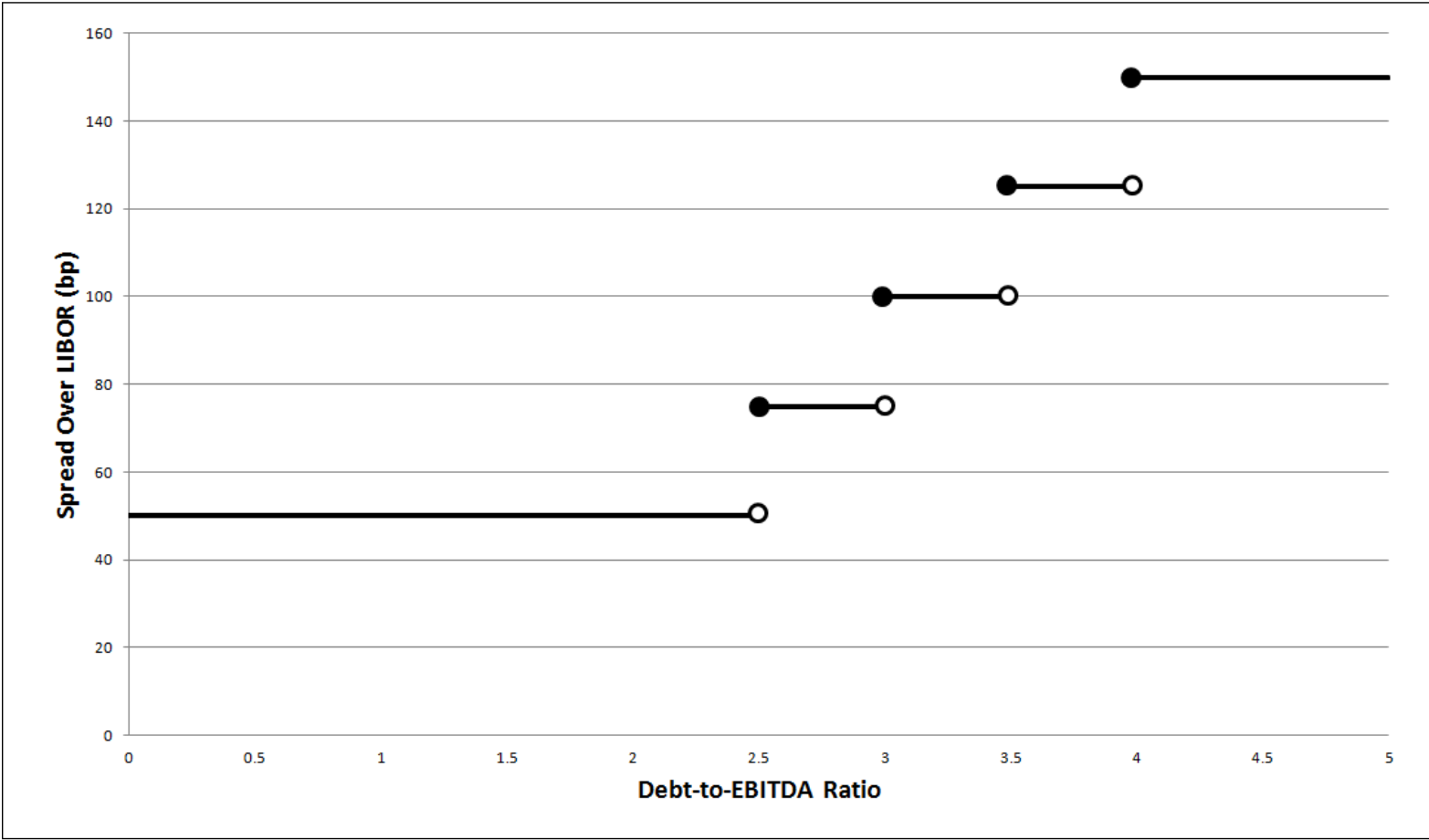


Figure 2: Rating-Based PSD

This figure shows the pricing grid of a loan issued by IBM in March 2004. The loan spread is a function of IBM's S\&P senior debt rating. IBM's senior debt rating at the time of loan issue was $\mathrm{A}+$. The initial spread paid was LIBOR $+12 \mathrm{bp}$.

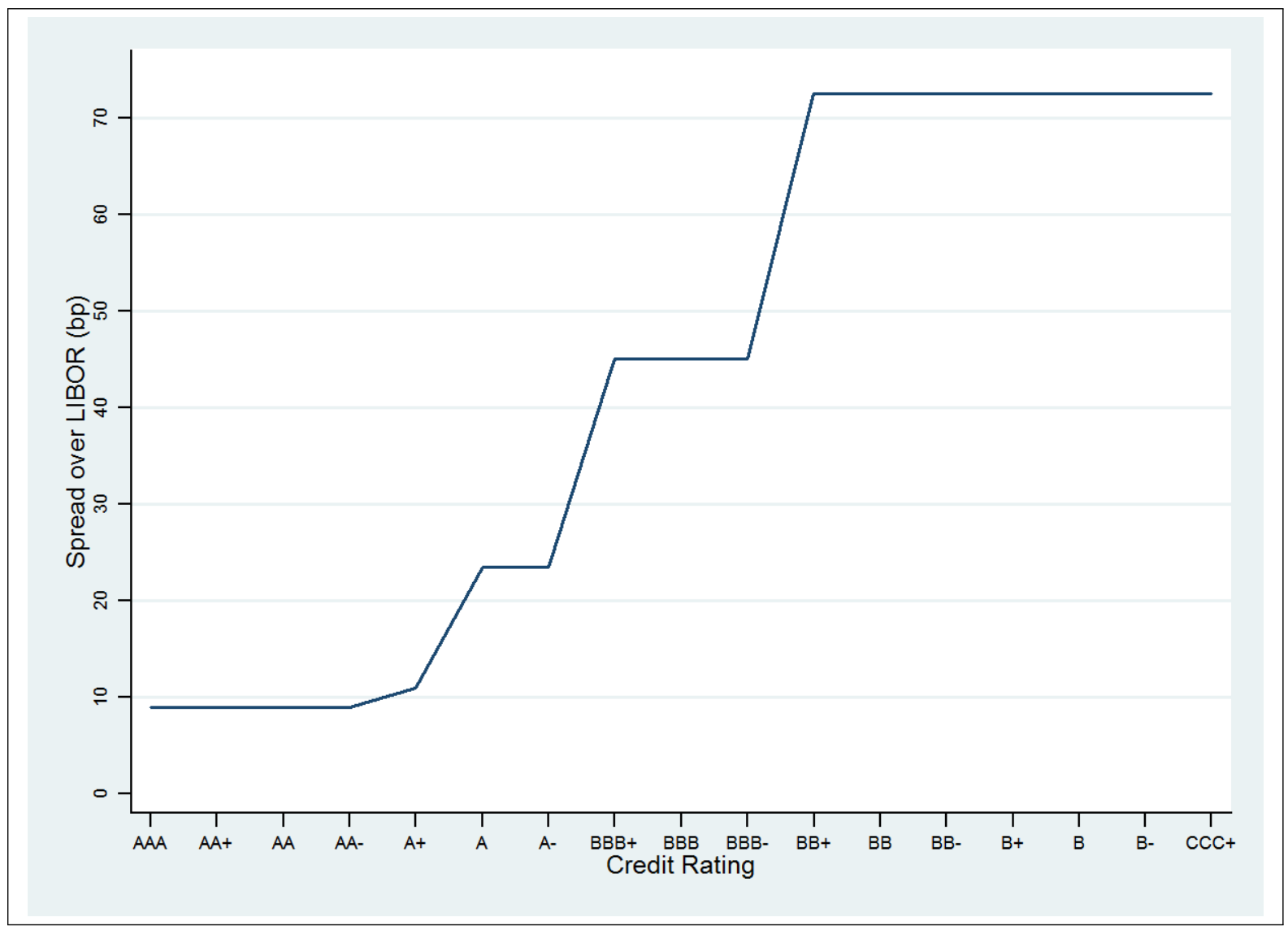




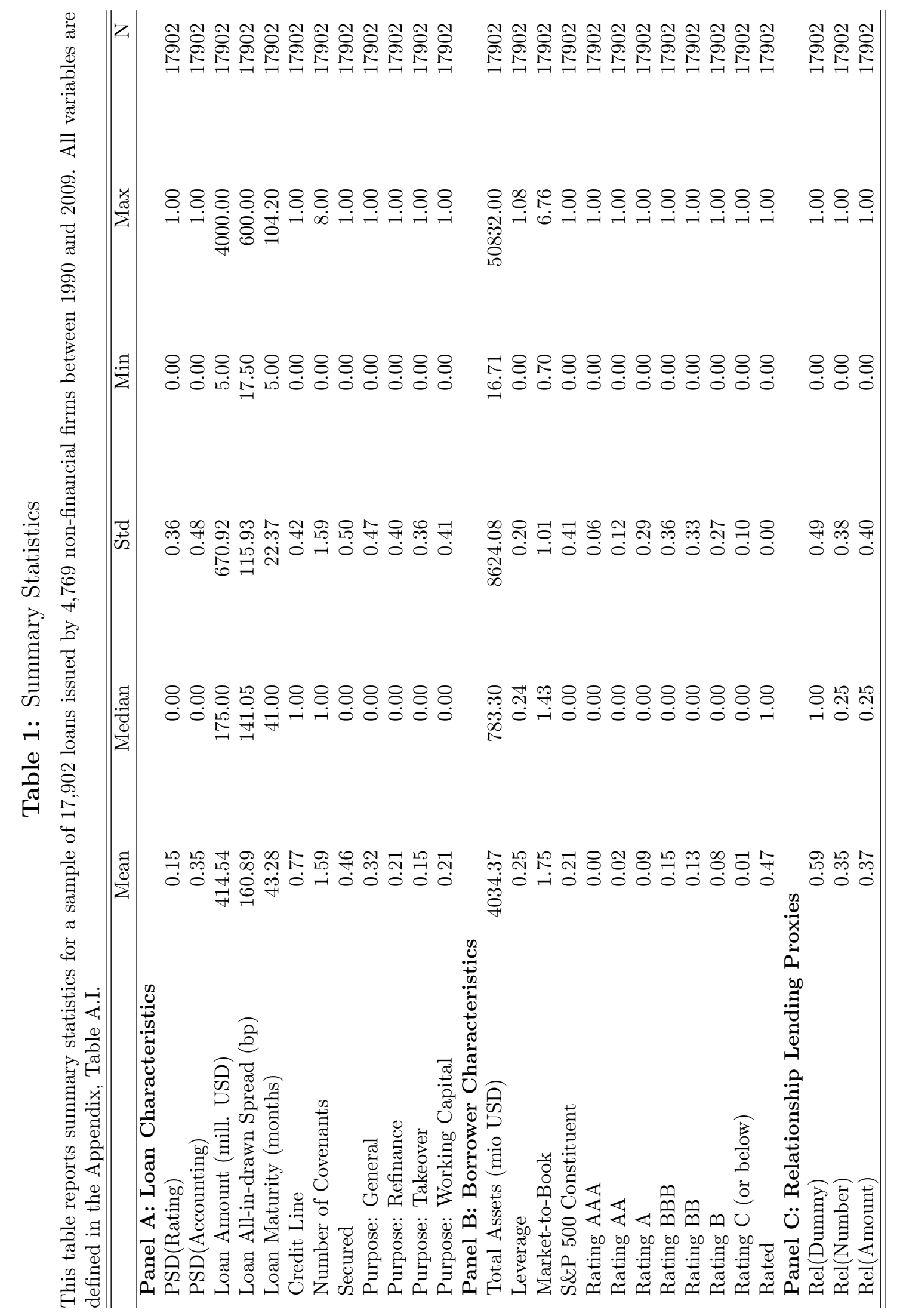


Table 2: PSD Contract Types

This table reports the types and frequencies of performance-pricing provisions used in our sample of PSD loans.

\begin{tabular}{lrr}
\hline \hline & Frequency & Observations \\
\hline Accounting-Based PSD & & \\
Debt-to-EBITDA & 0.44 & 4010 \\
User Condition & 0.07 & 644 \\
Multiple benchmarks & 0.05 & 463 \\
Leverage & 0.04 & 369 \\
Senior Debt to Cash Flow & 0.03 & 234 \\
Fixed Charge Coverage & 0.02 & 217 \\
Outstandings & 0.02 & 217 \\
Debt-to-Tangible Net Worth & 0.02 & 161 \\
Other Accounting Measures & 0.02 & 151 \\
Interest Coverage & 0.01 & 123 \\
Rating-Based PSD & & \\
Senior Debt Rating & 0.27 & 2484 \\
\hline Total & 1 & 9073 \\
\hline \hline
\end{tabular}




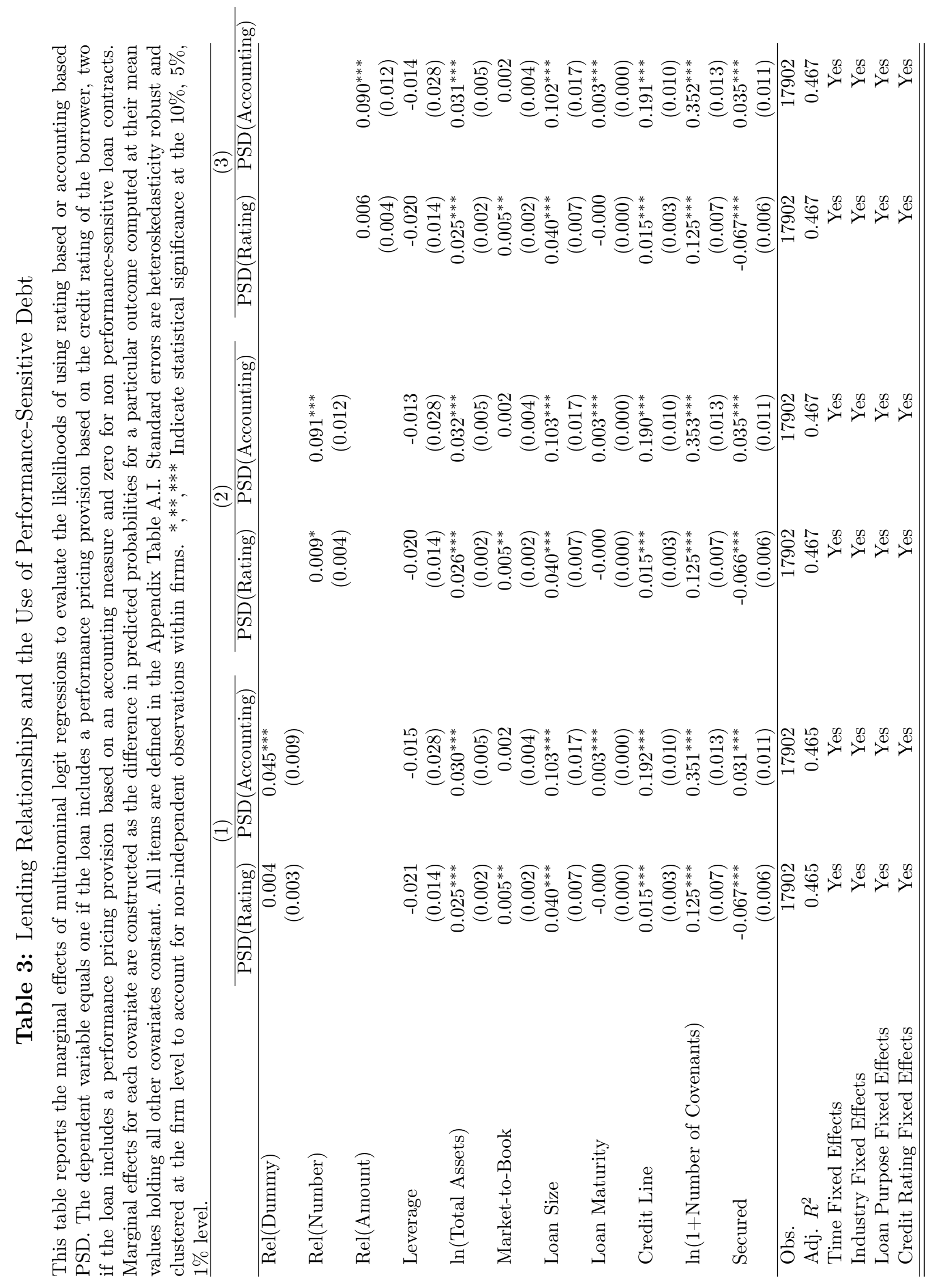




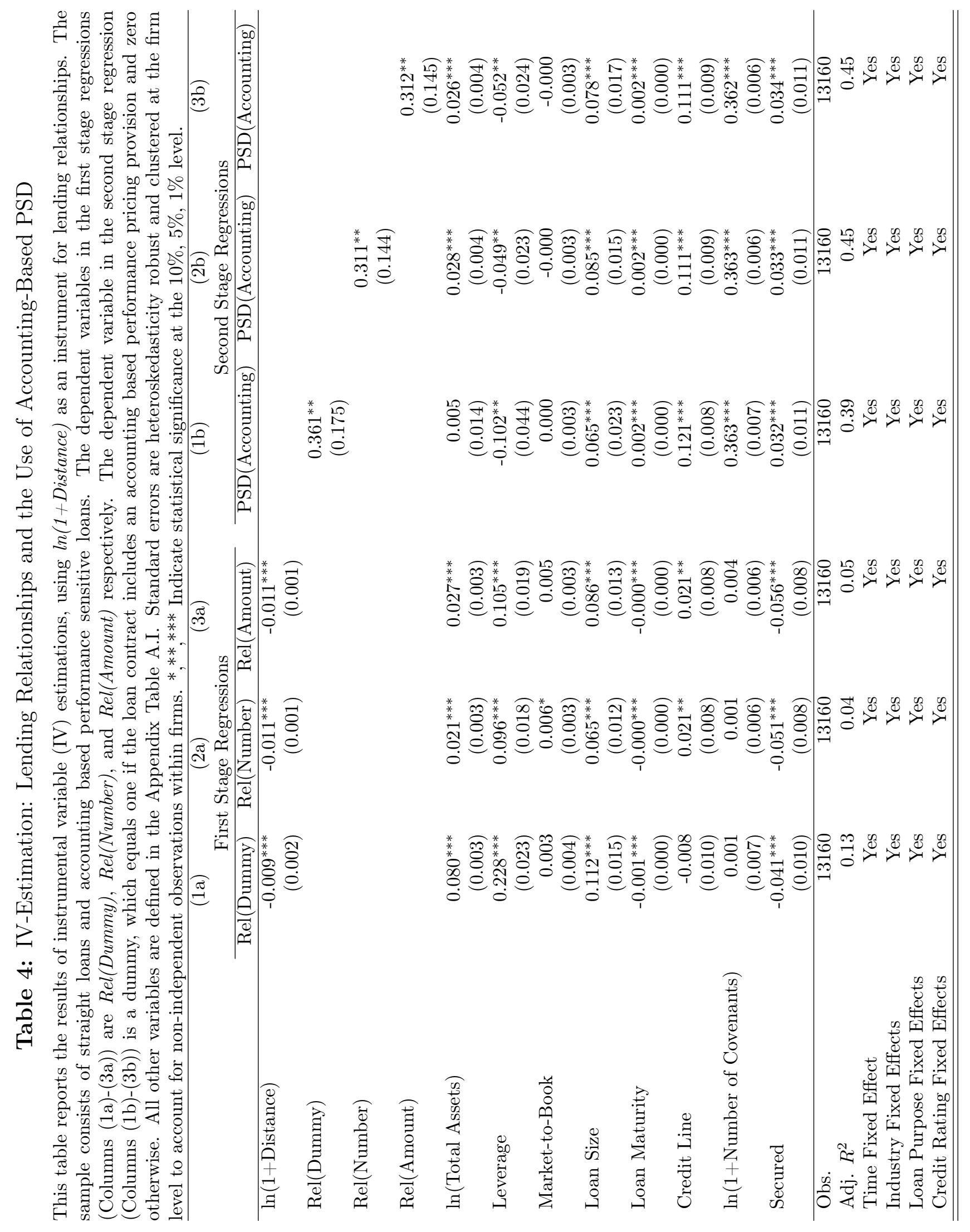




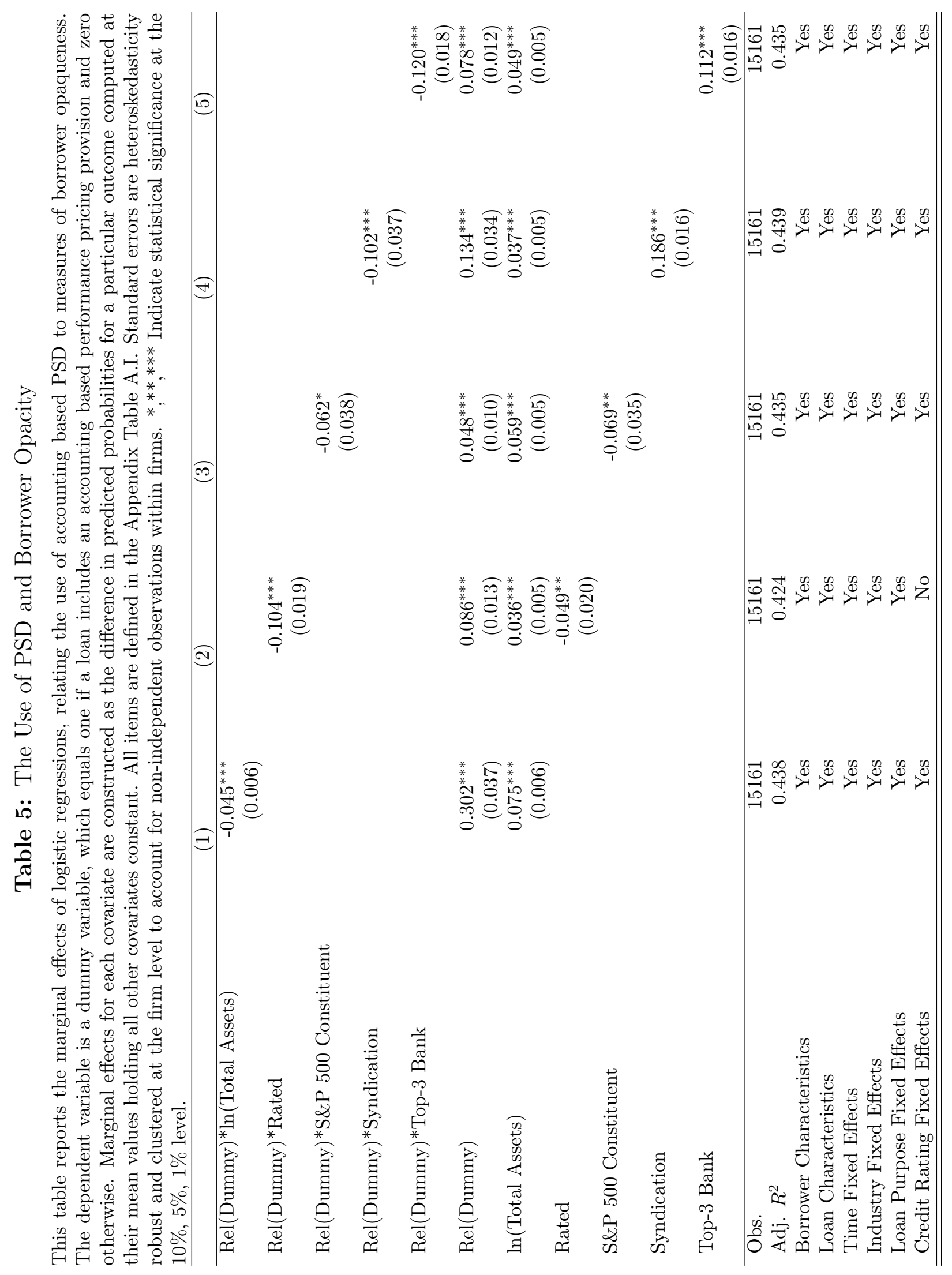


Table 6: The Use of Covenants in PSD vs. Non-PSD Contracts

This table reports the frequencies of covenants types used in accounting-based PSD and non-PSD contracts between 1990 and 2009. The last column reports differences in the frequencies and two-sample t-tests.

\begin{tabular}{|c|c|c|c|}
\hline & $\mathrm{PSD}(\mathrm{Acc})$ & Non-PSD & t-test \\
\hline \multicolumn{4}{|l|}{ Panel A: Leverage Covenants } \\
\hline Max. Debt-to-Tangible Net Worth & 0.06 & 0.06 & $\begin{array}{r}0.01 \\
(0.00)\end{array}$ \\
\hline Max. Debt-to-EBITDA & 0.64 & 0.11 & $\begin{array}{r}0.54^{* * *} \\
(0.01)\end{array}$ \\
\hline Max. Senior Debt-to-EBITDA & 0.13 & 0.02 & $\begin{array}{r}0.11^{* * *} \\
(0.00)\end{array}$ \\
\hline Max. Debt-to-Equity & 0.00 & 0.00 & $\begin{array}{r}0.00 \\
(0.00)\end{array}$ \\
\hline Max. Senior Leverage & 0.00 & 0.00 & $\begin{array}{c}0.00^{* *} \\
(0.00)\end{array}$ \\
\hline Max. Leverage & 0.11 & 0.04 & $\begin{array}{r}0.08^{* * *} \\
(0.00)\end{array}$ \\
\hline Max. Loan-to-Value & 0.00 & 0.00 & $\begin{array}{r}0.00 \\
(0.00)\end{array}$ \\
\hline \multicolumn{4}{|l|}{ Panel B: Coverage Covenants } \\
\hline Min. Cash Interest Coverage & 0.01 & 0.00 & $\begin{array}{r}0.01^{* * *} \\
(0.00)\end{array}$ \\
\hline Min. Debt Service Coverage & 0.08 & 0.03 & $\begin{array}{r}0.04^{* * *} \\
(0.00)\end{array}$ \\
\hline Min. Fixed Charge Coverage & 0.46 & 0.09 & $\begin{array}{r}0.37^{* * *} \\
(0.01)\end{array}$ \\
\hline Min. Interest Coverage & 0.38 & 0.09 & $\begin{array}{r}0.30^{* * *} \\
(0.01)\end{array}$ \\
\hline \multicolumn{4}{|l|}{ Panel C: Liquidity Covenants } \\
\hline Min. Current Ratio & 0.12 & 0.04 & $\begin{array}{r}0.08^{* * *} \\
(0.00)\end{array}$ \\
\hline Min. Quick Ratio & 0.02 & 0.01 & $\begin{array}{r}0.00 \\
(0.00)\end{array}$ \\
\hline \multicolumn{4}{|l|}{ Panel D: Other Covenants } \\
\hline Max. Capex & 0.24 & 0.07 & $\begin{array}{r}0.17^{* * *} \\
(0.01)\end{array}$ \\
\hline Min. EBITDA & 0.08 & 0.04 & $\begin{array}{r}0.04^{* * *} \\
(0.00) \\
\end{array}$ \\
\hline
\end{tabular}




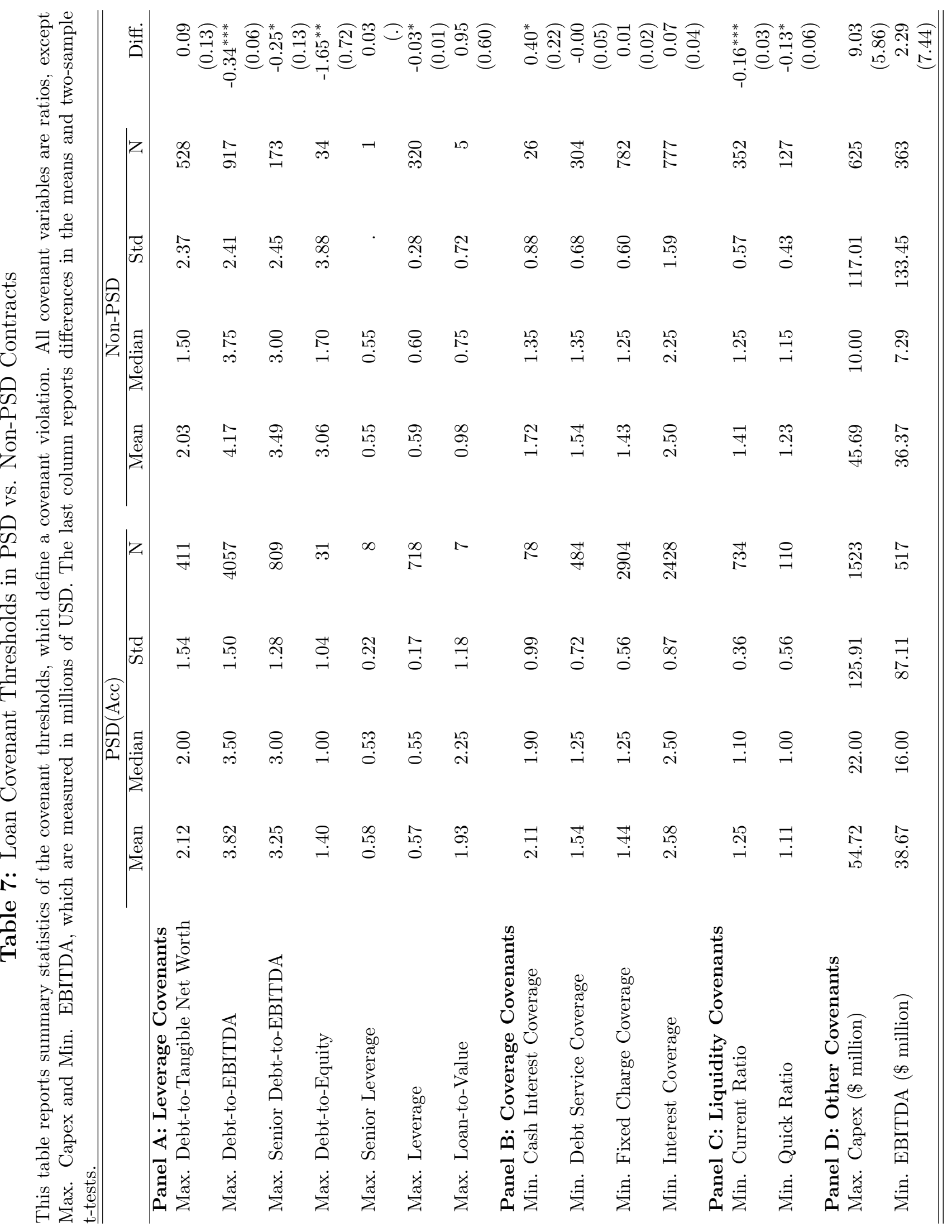




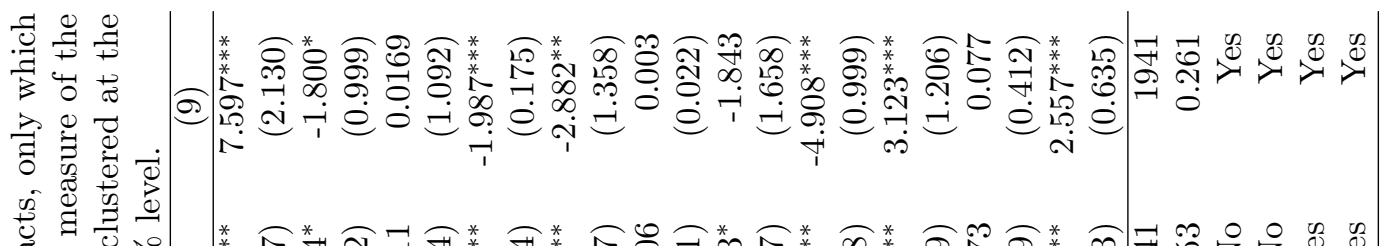

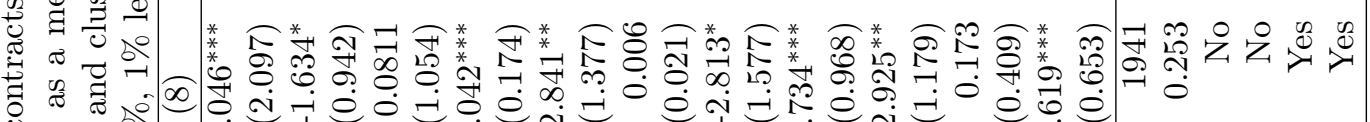

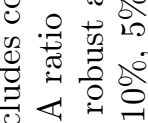

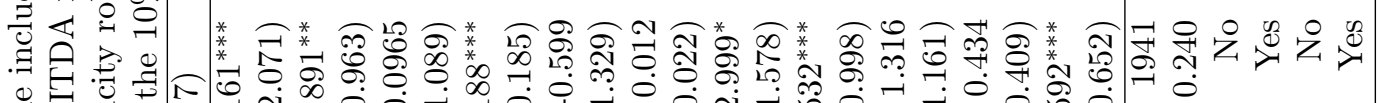

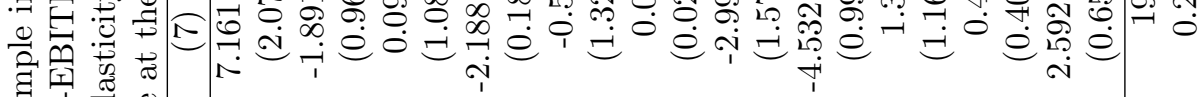

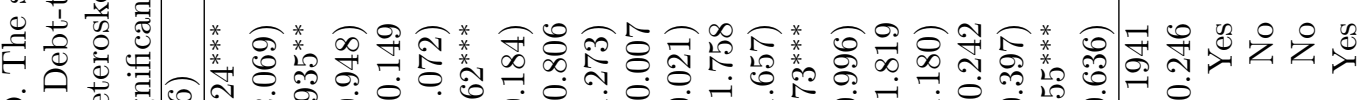

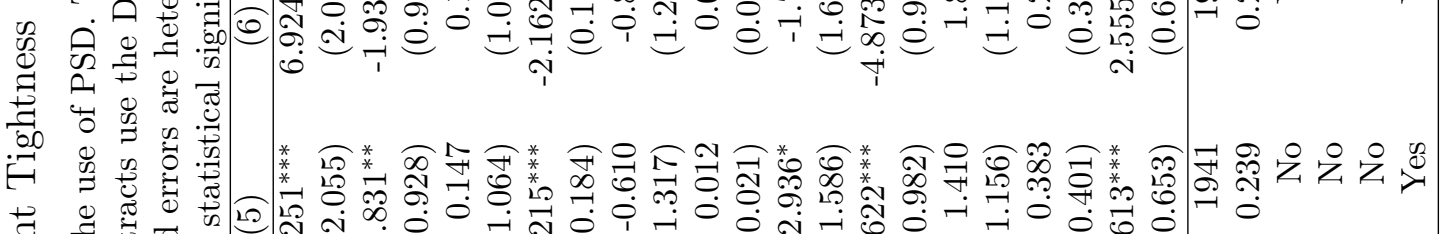

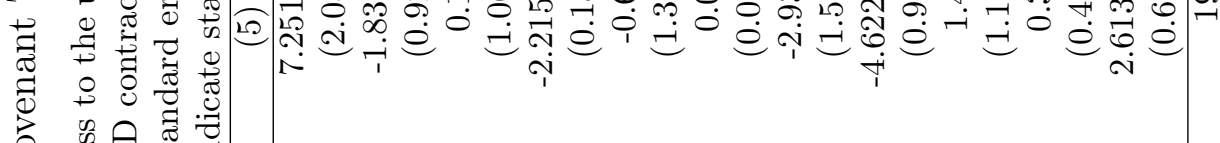

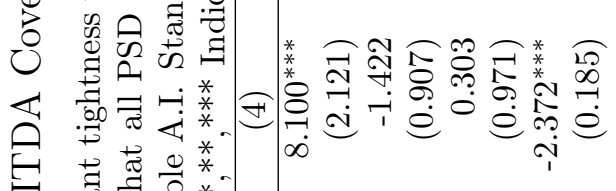

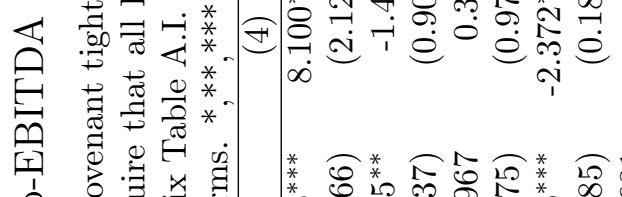

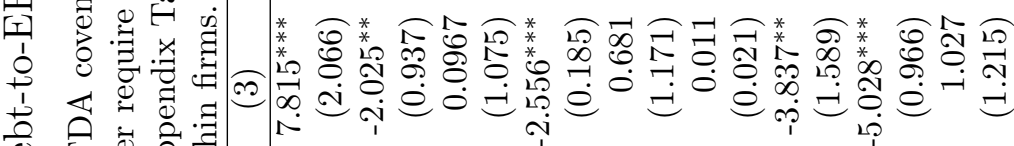

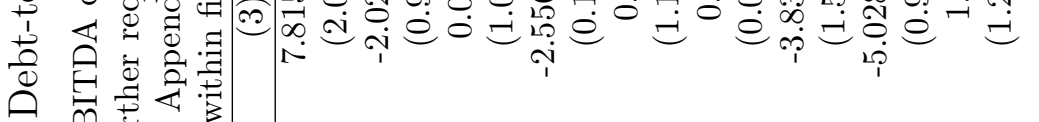

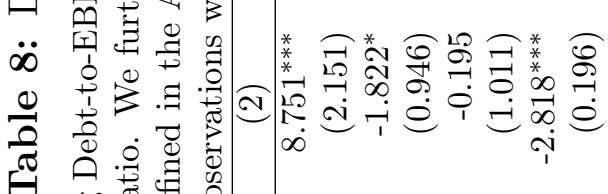

两

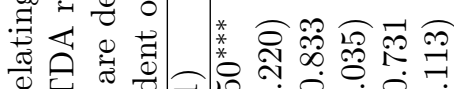

过

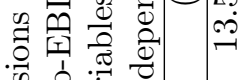

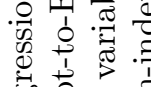

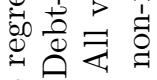

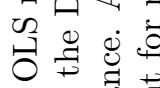

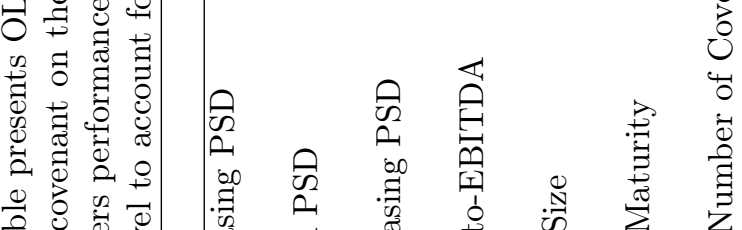

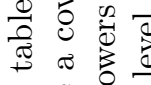

急总语圆

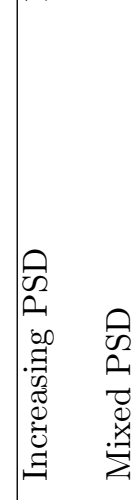

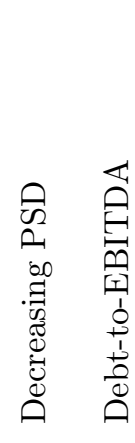

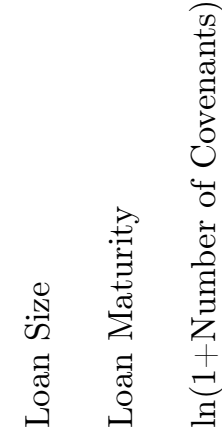

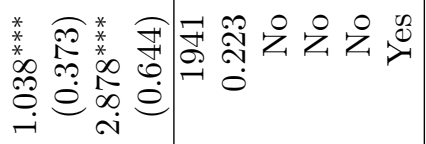

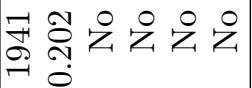

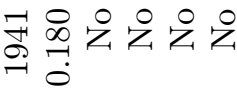

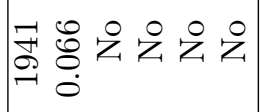




\section{Table 9: Ex-Post Rating Performance}

This table reports the coefficient estimates of ordered probit regressions to examine credit rating changes of the borrower after the issue of a PSD. The dependent variable can take on one of three values: 1 if the borrower's credit rating improved in the first $i$ quarters after the loan issue; -1 if the borrower's credit rating deteriorated in the first $i$ quarters after the loan issue; 0 if the borrower's credit rating remained unchanged in the the first $i$ quarters after the loan issue $(i=2,4,8)$. Initial Rating is the credit rating of the borrower at the time of loan issue $(1=\mathrm{AAA}, 2=\mathrm{AA}, \ldots)$. All other variables are defined in the Appendix Table A.I. Standard errors are heteroskedasticity robust and clustered at the firm level to account for non-independent observations within firms. ***,*** Indicate statistical significance at the $10 \%, 5 \%, 1 \%$ level.

\begin{tabular}{|c|c|c|c|}
\hline & (1) & $(2)$ & $(3)$ \\
\hline & +2 Quarter & +4 Quarter & +8 Quarter \\
\hline \multirow[t]{2}{*}{ PSD(Rating) } & $0.106^{* *}$ & $0.137^{* * *}$ & $0.142^{* * *}$ \\
\hline & $(0.046)$ & $(0.042)$ & $(0.042)$ \\
\hline \multirow[t]{2}{*}{ PSD(Accounting) } & $0.108^{*}$ & 0.083 & 0.043 \\
\hline & $(0.059)$ & $(0.054)$ & $(0.056)$ \\
\hline \multirow[t]{2}{*}{$\ln ($ Total Assets $)$} & $0.070^{* * *}$ & $0.078^{* * *}$ & $0.070^{* * *}$ \\
\hline & $(0.016)$ & $(0.017)$ & $(0.022)$ \\
\hline \multirow[t]{2}{*}{ Leverage } & -0.160 & $-0.227^{* *}$ & $-0.204^{*}$ \\
\hline & $(0.112)$ & $(0.114)$ & $(0.118)$ \\
\hline \multirow[t]{2}{*}{ Market-to-Book } & $0.316^{* * *}$ & $0.336^{* * *}$ & $0.313^{* * *}$ \\
\hline & $(0.024)$ & $(0.026)$ & $(0.028)$ \\
\hline \multirow[t]{2}{*}{ Loan Size } & $-0.496^{* * *}$ & $-0.446^{* * *}$ & $-0.431^{* * *}$ \\
\hline & $(0.093)$ & $(0.084)$ & $(0.087)$ \\
\hline \multirow[t]{2}{*}{ Loan Maturity } & $0.003^{* * *}$ & $0.002^{* * *}$ & $0.001^{* *}$ \\
\hline & $(0.000)$ & $(0.000)$ & $(0.000)$ \\
\hline \multirow[t]{2}{*}{$\ln (1+$ Number of Covenants $)$} & $-0.096^{* *}$ & $-0.103^{* * *}$ & $-0.084^{* *}$ \\
\hline & $(0.038)$ & $(0.034)$ & $(0.035)$ \\
\hline \multirow[t]{2}{*}{ Initial Rating } & $0.107^{* * *}$ & $0.124^{* * *}$ & $0.136^{* * *}$ \\
\hline & $(0.008)$ & $(0.008)$ & $(0.009)$ \\
\hline Obs. & 8132 & 7922 & 7433 \\
\hline Pseudo $R^{2}$ & 0.071 & 0.075 & 0.072 \\
\hline Time Fixed Effect & Yes & Yes & Yes \\
\hline Industry Fixed Effects & Yes & Yes & Yes \\
\hline
\end{tabular}




\section{SFB 649 Discussion Paper Series 2013}

For a complete list of Discussion Papers published by the SFB 649, please visit http://sfb649. wiwi.hu-berlin.de.

001 "Functional Data Analysis of Generalized Quantile Regressions" by Mengmeng Guo, Lhan Zhou, Jianhua Z. Huang and Wolfgang Karl Härdle, January 2013.

002 "Statistical properties and stability of ratings in a subset of US firms" by Alexander B. Matthies, J anuary 2013.

003 "Empirical Research on Corporate Credit-Ratings: A Literature Review" by Alexander B. Matthies, January 2013.

004 "Preference for Randomization: Empirical and Experimental Evidence" by Nadja Dwenger, Dorothea Kübler and Georg Weizsäcker, January 2013.

005 "Pricing Rainfall Derivatives at the CME" by Brenda López Cabrera, Martin Odening and Matthias Ritter, January 2013.

006 "Inference for Multi-Dimensional High-Frequency Data: Equivalence of Methods, Central Limit Theorems, and an Application to Conditional Independence Testing" by Markus Bibinger and Per A. Mykland, January 2013.

007 "Crossing Network versus Dealer Market: Unique Equilibrium in the Allocation of Order Flow" by Jutta Dönges, Frank Heinemann and Tijmen R. Daniëls, J anuary 2013.

008 "Forecasting systemic impact in financial networks" by Nikolaus Hautsch, Julia Schaumburg and Melanie Schienle, January 2013.

009 "'I'll do it by myself as I knew it all along': On the failure of hindsightbiased principals to delegate optimally" by David Danz, Frank Hüber, Dorothea Kübler, Lydia Mechtenberg and Julia Schmid, January 2013.

010 "Composite Quantile Regression for the Single-Index Model" by Yan Fan, Wolfgang Karl Härdle, Weining Wang and Lixing Zhu, February 2013.

011 "The Real Consequences of Financial Stress" by Stefan Mittnik and Willi Semmler, February 2013.

012 "Are There Bubbles in the Sterling-dollar Exchange Rate? New Evidence from Sequential ADF Tests" by Timo Bettendorf and Wenjuan Chen, February 2013.

013 "A Transfer Mechanism for a Monetary Union" by Philipp Engler and Simon Voigts, March 2013.

014 "Do High-Frequency Data Improve High-Dimensional Portfolio Allocations?" by Nikolaus Hautsch, Lada M. Kyj and Peter Malec, March 2013.

015 "Cyclical Variation in Labor Hours and Productivity Using the ATUS" by Michael C. Burda, Daniel S. Hamermesh and J ay Stewart, March 2013.

016 "Quantitative forward guidance and the predictability of monetary policy - A wavelet based jump detection approach -" by Lars Winkelmann, April 2013.

017 "Estimating the Quadratic Covariation Matrix from Noisy Observations: Local Method of Moments and Efficiency" by Markus Bibinger, Nikolaus Hautsch, Peter Malec and Markus Reiss, April 2013.

018 "Fair re-valuation of wine as an investment" by Fabian Y.R.P. Bocart and Christian M. Hafner, April 2013.

019 "The European Debt Crisis: How did we get into this mess? How can we get out of it?" by Michael C. Burda, April 2013.

\section{SFB 649, Spandauer Straße 1, D-10178 Berlin http:/ / sfb649.wiwi.hu-berlin.de}

This research was supported by the Deutsche Forschungsgemeinschaft through the SFB 649 "Economic Risk".

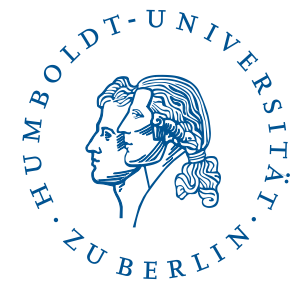




\section{SFB 649 Discussion Paper Series 2013}

For a complete list of Discussion Papers published by the SFB 649, please visit http://sfb649. wiwi.hu-berlin.de.

020 "Disaster Risk in a New Keynesian Model" by Maren Brede, April 2013.

021 "Econometrics of co-jumps in high-frequency data with noise" by Markus Bibinger and Lars Winkelmann, May 2013.

022 "Decomposing Risk in Dynamic Stochastic General Equilibrium" by Hong Lan and Alexander Meyer-Gohde, May 2013.

023 "Reference Dependent Preferences and the EPK Puzzle" by Maria Grith, Wolfgang Karl Härdle and Volker Krätschmer, May 2013.

024 "Pruning in Perturbation DSGE Models - Guidance from Nonlinear Moving Average Approximations" by Hong Lan and Alexander Meyer-Gohde, May 2013.

025 "The 'Celtic Crisis': Guarantees, transparency, and systemic liquidity risk" by Philipp König, Kartik Anand and Frank Heinemann, May 2013.

026 "State Price Densities implied from weather derivatives" by Wolfgang Karl Härdle, Brenda López-Cabrera and Huei-Wen Teng, May 2013.

027 "Bank Lending Relationships and the Use of Performance-Sensitive Debt" by Tim R. Adam and Daniel Streitz, May 2013. 